Yayınlayan: Ankara Üniversitesi KASAUM

Adres: Kadın Sorunları Araştırma ve Uygulama Merkezi, Cebeci 06590 Ankara

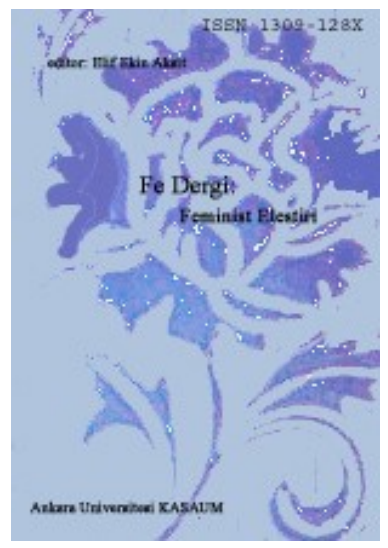

Fe Dergi: Feminist Eleştiri Cilt 2 Sayı 2

Erişim bilgileri, makale sunumu ve ayrıntılar için:

http://cins.ankara.edu.tr/

Unutulan bir Göç ve Yurttaşlık Deneyimi: İlk Kuşak

Göçmen Kadınlar ve Hollanda Türkiyeli Kadınlar

Birliği

Ece Öztan

Çevrimiçi yayına başlama tarihi: 20 Aralık 2010

Bu makaleyi alıntılamak için: Ece Öztan, "Unutulan bir Göç ve Yurttaşlık Deneyimi: İlk Kuşak Göçmen Kadınlar ve Hollanda Türkiyeli Kadınlar Birliği," Fe Dergi 2, no. 2 (2010): 31-49.

URL: http://cins.ankara.edu.tr/goc2.html

Bu eser akademik faaliyetlerde ve referans verilerek kullanılabilir. Hiçbir şekilde izin alınmaksızın çoğaltılamaz. 


\section{Unutulan bir Göç ve Yurttaşlık Deneyimi: İlk Kuşak Göçmen Kadınlar ve Hollanda Türkiyeli} Kadınlar Birliği

Ece Öztan ${ }^{*}$

Günümüzde "göçün kadınsılaşması” olgusunun kabulüne rağmen, ana akım göç araştırmalarında toplumsal cinsiyeti analitik bir kavram olarak kullanan ve göç alıcı ülke bağlamında göçmen kadınların deneyimlerine ışı tutan çalışmalar çok yaygın değildir. Özellikle misafir işçilik rejimlerinin geleneksel "aile birleşimi" temelli göç şemalarında kadınların göçü halen "ikincil” ve "bağımlı" göç olarak tanımlanmaya devam etmekte, göçmen kadınların iş piyasası, siyasal katılım ve yurttaşlık gibi konularda katkllart ihmal edilmektedir. Bu makalede kadınların özellikle topluluk hizmetlerinin örgütlenmesi ve yurttaşlık mücadelesi açısından oynadıkları rolleri 1974 yılında kurulan Hollanda Türkiyeli Kadınlar Birliği (HTKB) ve birliğin faaliyetlerine aktif olarak katılan kadınların deneyimleri üzerinden incelemeyi hedefliyorum. Çalışma, 2007-2008 yıllarında Hollanda'da gerçekleştirilen, eski HTKB'li kadınlarla yapılan derinlemesine görüşmeler ve HTKB arşivinden elde edilen verileri de içeren daha geniş bir nitel alan araştırmasına dayanmaktadır. Makalenin giriş bölümünde göç ve toplumsal cinsiyet ilişkisi üzerinde duracağım. İkinci bölümde, Hollanda'da ilk kuşak Türkiye kökenli kadınların iş piyasası ve topluluk hizmetlerindeki deneyimlerine, bunu takip eden bölümde ise özel olarak HTKB deneyimine odaklanacă̆ım. Bu deneyimlerden hareketle makale, son dönemlerde göçmen kökenli kadınları neoliberal bir yurttaşlık çerçevesinden bir "problem kategorisi" olarak inşa eden entegrasyon ve özgürleşim perspektifine yönelik eleştiriler ile son bulacaktır.

Anahtar Kelimeler: Göç ve toplumsal cinsiyet; misafir işçilik rejimleri, Hollanda, Türkiye kökenli göçmen kadınlar, göçmen kadın örgütlenmeleri

\section{A forgotten migration and citizenship experience: First generation immigrant women and The Netherlands Union of Women from Turkey}

Despite acknowledging the feminization of immigration there are a few studies giving immigrant and ethnic minority women greater visibility within receiving country context and using gender as an analytic concept in migration researches. Particularly, there is a tendency that women's migration has still been acknowledged as "dependant" or "secondary" migratory movement in guest worker regimes' traditional "family reunion" schemas and issues such as immigrant women's participation in labour markets, politics and citizenship have been ignored. In this article, I aim to examine immigrant women's role especially in community services and citizenship struggles focusing on Hollanda Türkiyeli Kadınlar Birliği (The Netherlands Union of Women from Turkey) founded in 1974 and participant women's experiences. This study is based on a larger fieldwork conducted in 2007-2008 in the Netherlands including in-depth interviews with women who were previously active in HTKB and the data review from $H T K B$ archives. In the introduction chapter, I review gender and migration relationship in literature. In the second chapter, I focus on first generations Turkish immigrant women's experiences in labour market and community organization in Dutch context and following chapter specifically their experiences in $H T K B$. Finally, from the vantage point of immigrant women's experiences, the article concludes with critics on current political frameworks in the Netherlands based on a neoliberal citizenship perspective that construct immigrant women as a "problem category".

Key words: Migration and gender; guest worker regimes; the Netherlands; immigrant women from Turkey; immigrant women organizations

\footnotetext{
"Yıldız Teknik Üniversitesi.
} 


\section{Giriş}

\section{Göç ve Toplumsal Cinsiyet}

Göçün erkeğe özgü bir serüven olduğu inancı uzunca bir dönem egemenliğini korumuştur ${ }^{1}$. Kadınların göçüne ilişkin bu yaklaşımın akademide de karşılığı vardır. 1984 yılında International Migration Review'de, göç ve kadın konulu özel bir sayı derlenmişti. Derlemeyi hazırlayan Morokvasic'in "Birds of passages are also women" başlıklı sunuş makalesi, yalnızca göç araştırmalarında kadınların görünmezliğine değil, göç literatürünün toplumsal cinsiyet duyarsızlığına, ortaya konan kuram ve modellerin "erkek yanlılığına" vurgu yapıyordu. ${ }^{2}$ Gerçekten de göç araştırmaları uzunca bir dönem kadınlara ilgisiz kalmıştı. ${ }^{3} \mathrm{Bu}$ dönemde kadınlar erkeklerin aldığı göç kararlarını takip eden ve bu nedenle gerek göç süreci içerisindeki, gerekse iş piyasasındaki konumları bakımından "bağımlı", "pasif” bir kategori olarak ele alınmaktaydı. ${ }^{4}$

Özellikle 1990’lı yıllardan itibaren "göçün kadınsılaşması" olgusuna dikkat çekilmeye başlanmıştır. Ancak bu olguya değinen pek çok çalışmada dahi, bağımsız kadın göçünün farklı dönem ve türleri, göç süreçleri bakımından önemi gibi konular ihmal edilmiştir. ${ }^{6}$ Göç süreçlerine ilişkin şemalarda, özellikle daha önceki dönemlere ilişkin kadın göçü, ikincil ve bağımlı göç olarak tanımlanmaya devam etmektedir. Oysa kadınların göçü, misafir işçilik döneminde de heterojen nitelikler göstermekteydi. Örneğin bağımsız kadın göçü sadece "göçün kadınsılaştığı" döneme özgü olmayıp, uluslararası göçün farklı dönemlerinde de süregelen bir göç türüydü. ${ }^{7}$ Klasik göç şemaları, aile birleşimi yoluyla gelseler dahi, kadınların iş piyasasındaki katkılarının yanı sıra, toplumsal cinsiyetin kurumsal yapı ve süreçlerle ilişkisinin de gözden kaçırılmasına yol açmıştır. Bu nedenle yurttaşlık, siyasal katılım gibi konularda göçmen kadınların görünmezliği devam etmiştir. Oysa kadınlar, göç edilen ülkeye yerleşme ve topluluk hizmetlerinin örgütlenmesinde, göçmenlere yönelik sosyal hizmet alanlarının oluşumu ve gelişiminde, sivil katılım süreçleri ile ana toplumla kurdukları bağlar yoluyla göçün sürdürülmesi ve entegrasyon süreçlerinde de önemli roller oynamaktadır. Yurttaşlığın doğrudan gündelik yaşam içerisinde kurulumuna işaret eden bu alanların her biri ayrı bir incelemenin konusu olabilir.

$\mathrm{Bu}$ makalede kadınların özellikle topluluk hizmetlerinin örgütlenmesi açısından oynadıkları rolleri 1974 yılında kurulan Hollanda Türkiyeli Kadınlar Birliği (HTKB) ve birliğin faaliyetlerine aktif olarak katılan kadınların deneyimleri üzerinden incelemeyi hedefliyorum. Makale, 2007-2008 yıllarında Hollanda'da feminist bakış açısı kuramına dayanan epistemolojik çerçevede gerçekleştirdiğim daha geniş bir nitel alan araştırmasına dayanmaktadır ${ }^{8}$. Makalede, aralarında HTKB'nin kurucu kadrosunda yer almış ve çalışmalarına aktif olarak katılmış kadınları da içeren toplam 44 kadınla yaptığım derinlemesine görüşmeler ile HTKB ve Hollanda'da Türkiye kökenli kadınların tarihine ilişkin arşiv malzemesinden yararlandım. HTKB deneyimine geçmeden önce, önce Türkiye kökenli kadınların Avrupa'ya göçüne ilişkin literatüre ve özel olarak Hollanda'daki Türkiye kökenli kadınların göç deneyimlerine biraz daha yakından bakmaya çalışacağım.

\section{Avrupa “Misafir Iş̧̧ilik” Rejimlerinde Türkiye Kökenli Kadınlar}

1960'lı y1llardan itibaren Avrupa'da görülen "misafir işçilik” rejimlerine ilişkin olarak kapsamlı bir literatür gelişmesine rağmen, içerdiği çeşitlilik ve farklılıklara rağmen kadınların bu göç süreci içerisindeki yeri ve konumuna ilişkin incelemeler oldukça kısıtlıdır. 1990'lardan itibaren genel olarak kadınların göçüne ilişkin akademik bir ilginin canlandığı görülse de, göçmen işçilik rejimleri ve tarihine ilişkin çalışmaların çoğunda kadınların konumu "aile birleşimi”" kategorisi ile oldukça sınırlayıcı genellemeler temelinde incelenmektedir. Kosack, daha 1970'li yıllarda, özellikle Almanya ve İsviçre'de iş piyasasına aktif olarak katılan göçmen kadınların, çalışmayanlara göre daha geniş bir grup olduğuna vurgu yaparak, literatürün özellikle çalışmayan göçmen kadın üzerine odaklanmasındaki eksikliğe dikkat çekmektedir.' Abadan-Unat'ın, 1960'lı yıllardan itibaren Türkiye kökenli kadınların Almanya iş piyasasındaki konumlarına yer verdiği çalışmalar bunun bir istisnasını oluşturmaktadır. ${ }^{10}$ Abadan-Unat özellikle 1966'dan sonra, Türkiye kökenli kadın işçilerin oranındaki artışa dikkat çekmekte ve Türk kadınlarının Alman iş piyasasındaki deneyimlerini, arz ve talep koşullarını da dikkate alarak farklı dönemler ve içerdiği çeşitlilik bakımından incelemektedir. ${ }^{11}$ Türkiye kökenli kadınlar Almanya'da elektronik, otomativ, tekstil, kimya, gıda endüstrileri ile paketleme ve temizlik hizmetleri gibi alanlarda yoğunlaşmaya başlamış, özellikle tekstil alanında giderek yoğunlaşan kadın işgücü talebi diğer Avrupa ülkelerinde de göçmen kadın istihdamını tetiklemiştir. Keyder ve Aksu-Koç da özellikle tekstil alanındaki bu talebin, Türkiye'den Avrupa'ya kadın işçi göçü açısından önemli bir dönemeç olduğuna dikkat çekmekte, bu yolla önce kadın işçinin Avrupa'ya geldiği ve ardından eş ve yakın akrabaların aile birleşimi yolu ile göç 
sürecine dahil olduğu yeni bir modelin artış gösterdiğine değinmektedir. ${ }^{12}$ İşçi alımına ilişkin ikili anlaşmalar aile birleşimini garanti altına alırken, eşlerden birinin yasal çalışma iznine kavuşması halinde diğer eşe de çalışma izninin verilmesi kuralını içermekteydi. Abadan-Unat da, özellikle 1970’lere doğru Avrupa endüstrilerinin daha düşük maliyetli kadın işçilere yönelmesi eğilimi ile beraber, pek çok Türk kadınının, eşlerinin özlemini çektikleri "Batıdaki işiı" bulmak için yola çıktıklarına değinmektedir. ${ }^{13}$ Özellikle Almanya ve Hollanda gibi ülkelerde Türkiyeli kadınların işgücüne katılım oranları diğer Akdeniz ülkelerinin oldukça üzerinde gerçekleşmiştir. Örneğin Hollanda'da Yugoslavyalı kadınlar ile birlikte Türkiyeli kadınlar en yüksek katılım oranlarına sahipti. ${ }^{14}$ 1980 Çalışma Bakanlığı istatistiklerine göre iktisadi olarak aktif kadınlar, Avrupa'daki toplam Türkiye kökenli işçilerin \% 25'ini oluşturuyordu. ${ }^{15}$ Özellikle Almanya'da daha 1973'te göçmen kadınlar, toplam göçmen işgücünün \% 30'unu oluşturuyorlardı. Göçmen kadınların yarısından fazla iktisadi olarak aktifti ve bu oranlar örneğin Yugoslav kadınlar da \% 70’ler seviyesine çıkıyordu. Kosack'ın vurguladığı gibi bu oranlar hem geldikleri ülkelerin hem de Almanya'daki kadınların işgücüne katılım oranlarının ilerisindeydi. ${ }^{16}$ Almanya'da göçmen işçilik rejiminin zirve yıllarında, bekâr veya çocuklarını Türkiye'de bırakarak gelen pek çok evli kadın bulunmaktaydı. ${ }^{17}$ Buna rağmen göçmen işçilik rejimlerine ilişkin çalışmalar ağırlıklı olarak erkekler üzerine yoğunlaşmış, kadınların göçü genellikle bağımlı göç adı altında, misafir işçilerin eşleri olarak değerlendirilmiştir. 1980'li yılların ortalarından itibaren, toplumsal cinsiyetin göçe ilişkin daha makro süreçlerle nasıl eklemlendiğini araştıran alışmalar görülmeye başlanmıştır. ${ }^{18}$ Avrupa göç literatürünün erkek merkezliliği karşısında toplumsal cinsiyet vurgusuna dayanan çalışmalardan biri Annie Phizacklea'nın 1983'te derlediği Tek Yön Bilet: Göç ve Kadın İ̧̧gücü başlıklı çalışma olmuştur. ${ }^{19}$ Kadınların göç araştırmalarında yer almaya başladığı dönemlerde yaygınlık kazanan bir eğilim ise, Erder'in vurguladığı gibi, göçmen kadının bir “sorun” olarak gündeme gelmesi olmuştur. ${ }^{20}$ Kadınların göçmen olarak bağımlı kabul edilmelerine dayanan geleneksel nosyon, pek çok Avrupa ülkelerindeki göç mevzuatı ile de yeniden üretilmekteydi. Hondagneu-Sotelo'nun belirttiği bir diğer eğilim ise kadınların göç araştırmalarında "cinsiyet rolleri” paradigması ile yalnızca aileye ve özel alana ilişkin meselelerle ilişkili olarak ele alınmasıdır. Bu tür yaklaşımlar, cinsiyetlendirilmiş bir kamusal-özel ayrımına dayanmanın ötesinde, toplumsal cinsiyeti ailenin ötesindeki toplumsal kurumlar ve süreçlerle ilişkisiz bir şeymişçesine ele almışlardır. Göç ve toplumsal cinsiyet ilişkisinin hane ve sosyal ağlarla ilişkili bir alanda, diğer sosyal kurumlar ve makro süreçlerle ilişkisi kurulmadan ele alınması da bu marjinalleşmeye katkıda bulunmuştur. ${ }^{21}$ Toplumsal cinsiyetin göç araştırmalarına girmesinin ardından sıklıkla görülen bir eğilimin de göçün kadınlar için bir güçlenme ve toplumsal cinsiyet eşitliği yönünde bir ivme olarak kabul edildiği araştırmaların yaygınlık kazanmasıdır. Kuşkusuz göçün farklı bağlamlarda toplumsal cinsiyet ilişkilerine meydan okuduğu kabul edilse de, Pessar’ın işaret ettiği gibi bunun doğrudan kadınların gelir ve işe sahip olmasına dayandırılması ve düz bir ilişki olarak algılanmasının kimi sorunları vardır. ${ }^{22}$ Abadan-Unat, daha 1970'li yıllarda, Almanya'daki Türk kadınlarından hareketle, özgürleşme ve sözde-özgürleşme ikiliğine değinerek patriarka - göç ilişkisini daha incelikli bir şekilde analiz etmiştir. ${ }^{23}$ Almanya'daki ilk kuşak göçmen işçiler üzerine çalışmasında Miller, 1973 yılında çoğunluğunu Türkiye kökenli kadınların oluşturduğu Pierburg grevini analiz ederken, özgürleşme ile katılım ve yurttaşlık mücadelesi arasında bağ kurmaktadır. ${ }^{24}$ Bu grev, Batı Almanya'nın açıkça ayrımcı olan ücret kategorileri sisteminde değişiklik yaratması, göçmenlerin yurttaşlık mücadelesine girişerek "misafir işçilik" anlayışına meydan okuması ve kamuoyunda resmedildiğinin aksine göçmen kadınların, özgürleşme sürecinin özneleri olduklarını ortaya koyması bakımından önemlidir. Göçmen kadınların Avrupa iş piyasaları içerisinde konumları meselesi, 1980'li yıllar ve sonrasında Avrupa'nın hizmet temelli, esnekleşen ve ulusaşırılaşan neoliberal politik ekonomisi ile gözden düşen konulardan biri olmuştur.

Kadınların göç tarihine ilişkin, “aile birleşimi” kategorisinin ötesinde, göç sürecinin içerdiği çeşitlilik ve farklılıklara yer veren, daha geniş ve nüanslı araştırmalara ihtiyaç vardır. Göçün kadınlaşmasından bahsedildiği günümüzde, cinsiyetlenmiş göç örüntülerinin, istihdamdan, ailenin örgütlenmesine, topluluk aktivizminden, siyasal katılım ve yurttaşlık mücadelesine kadar farklı alanların geçişkenlikleri içerisinde anlaşılması gerekir. Birbirinden çok farklı motivasyonlar, deneyimler, milliyetler, faillik biçimleri ve ulusal göç rejimleri altında bu çeşitliği yakalamak, hem göç tarihinin ve göçmen kadınların Avrupa'daki varlığının yeniden ortaya konması hem de yeni dönemin ayırt edici yanlarını çıkarmak açısından önem taşımaktadır.

\section{“Bağımlı Göçmenden”, “Refah Bağımlısı” Yurttaşa Hollanda'da Göçmen Kadınlık}

Hollanda'ya Türkiye'den göç büyük ölçüde 1960'lı yılların “misafir işçilik” rejiminin etkisiyle gerçekleşmişti. ${ }^{25}$ Ana akım göç araştırmalarında misafir işçi göçü ile başlayıp, aile birleşimi ve kalıcı yerleşme aşamalarına dayanan göçün farklı aşamalarına ilişkin geleneksel model egemenliğini korumaktadır. Ancak işçi 
göçü ve aile birleşimine dair şematik dönemselleştirme sadece geliş yolları bakımından değil, farklı dönemler, motivasyonlar ve deneyimlerin çeşitliliğinin gözden kaçırılmasına sebep olmaktadır. Evlilik ve aile birleşimi Hollanda özelinde özellikle 70'lerin sonlarından itibaren Türkiye'den kadın göçünün önemli nedenlerinden bir olsa da, çeşitli saiklarla bağımsız kadın göçü de devam etmiştir. Kaldı ki aile birleşimi yolu, 1970'lerden sonra Avrupa'ya kalıcı göçün resmi olarak kabul edilen tek yolu haline geldiği düşünülürse, bu dönemden itibaren özellikle kadınların- bütün göç çeşitliliğini bu başlık altında incelemenin fazlasıyla sınırlayıcı olduğunu ileri sürebiliriz. Kofman'ın da ileri sürdüğü gibi aile birleşiminin bir yasal giriş yolu değil de bir göç türü ve dönemleştirmesi olarak sunulması, aile birleşimi ile göç eden kadınların "bağımlı göçmenler" olarak tanımlanması ve böylelikle de iş piyasasındaki konumları gibi meselelere ilgisiz kalınması sonucunu doğurmuştur. ${ }^{26}$

Türkiyeli kadınların Hollanda'ya göçü daha başından Almanya, İsviçre ve Avusturya gibi diğer misafir işçilik rejimlerindeki kadın göçünden kimi farklılıklar içeriyordu. Öncelikle ilk dönemlerden itibaren uluslararası ticaret ve yatırımlara dayanan gelişmiş bir ticaret kapitalizmi ile Hollanda diğer Avrupa ülkelerine oranla görece geç ve yavaş bir endüstrileşme süreci yaşamış ve endüstriyel kadın emeği her dönemde görece düşük bir seviyede kalmıştır. Uluslararası ticaretle bağlantılı alanlarda ve geç gelişen endüstrisine rağmen Hollanda, 19. yy'dan bu yana dünyanın en büyük çokuluslu yatırımcılarından biri olarak Avrupa'nın en zengin ülkeleri arasında yer almıştır. ${ }^{27}$ Bütün bu özellikler, göçmen işçilerin karşılaşacağı iş piyasaları bakımından Hollanda'yı pek çok Avrupa ülkesinden farklı bir konuma sokmaktadır. Örneğin 1961-74 döneminde Türkiye'den Hollanda'ya gidenler içinde kadınların oranı \% 1'in altındayken, bu oran kadınların pek çok endüstri dalında işe alındığı Almanya' da \% 21, İsviçre' de \% 15, Avusturya'da da \% 12'idi. İstihdam alanlarının özellikleri yanı sıra Hollanda, daha başından kadın işçilerin bekâr ve çocuksuz olmaları koşulunu aramakta, ilk dönemlerde yapılan göçmen işçilik sözleşmelerinde Almanya'dakinin aksine gelecek kişilerin ailesi veya yakınlarını getirmesi yasaklanmaktaydı. ${ }^{28}$ Oysa Almanya'da göçmen işçi statüsü ile bağımsız olarak gelen kadınların yanı sıra, eşleri ile birlikte veya takiben Almanya'ya gelen kadınlar da, Alman iş pazarına erken bir tarihte dahil olmaya başlamışlardı. Örneğin Almanya'da Türkiye kökenli göçmen işçiler içinde evli kadınların oranı \% 29'du. Almanya'daki çeşitli uyruklardan bütün misafir işçiler içinde ailelerini arkada bırakarak göç eden evli kadın sayısının en yüksek olduğu grup Türkiye kökenli göçmenlerdi. Almanya'nın bazı bölgelerinde, örneğin Berlin'de, 1973 tarihinde Türkiye kökenli grup içinde kadın işçilerin oranı \% 40 idi. Bu kadınların çoğu Bavaria ve Baden gibi eyaletlerdeki elektronik ve tekstil endüstrilerinde istihdam edilmişti. ${ }^{29}$ Yine genel olarak Hollanda'ya göçün, Almanya'ya oranla daha çok kırsal alanlardan gelenler ile vasıfsız işçilerden oluşması Almanya'ya ilk göç edenler içindeyse kent kökenli ve çalışma deneyimi olan kadınların bulunması gibi önemli farklılıklar istihdam örüntülerinde etkili olmuştur. ${ }^{30}$ Bütün bu özellikler, Hollanda’ya gelen kadınların koşullarını ve önlerindeki istihdam olanaklarını etkilemekteydi. Bu nedenle ilk dönemlerde Hollanda'ya bağımsız olarak, genellikle tekstil atölyelerinde çalışmak amacıyla gelen az sayıda kadının, oturum ve çalışma izni olmaksızın, kayıt-dışı alanlarda çalışmak üzere geldiği söylenebilir.

\section{“Tek Ayakla Koşmak”: İlk Kuşak Göçmen Kadınlar ve İş piyasası}

Hollanda'ya göç eden Türkiyeli kadınların oranı, 1967'de aileleri getirme yasağının kaldırılmasından sonra artmaya başlamış, özellikle 70'lerden itibaren aile birleşimi yoluyla gelen kadınların katılması ile kadınların oranı hızla yükselmiştir. 70'lerin başlarında gelen kadınların birçoğunun, erkek göçmen işçilerin aile birleşimi yoluyla Hollanda'ya gelen eş ve kız çocukları olduğu düşünülebilir. Ancak Hollanda'da genel göç istatistikleri sığınma, çalışma, evlilik vb. gibi göç etme nedenlerini içermediği için, gelen kadınların ne kadarının çalışmak için bağımsız olarak geldiği bilinmemektedir. Araştırma kapsamında görüştüğüm kadınların 11 'i 1 . kuşak, 12'si ise 1,5. kuşak yani misafir işçilerin, 6 yaşından sonraki dönemde Hollanda'ya gelen kız çocuklarından oluşan gruptur. ${ }^{31} 1$ ve 1,5 . kuşak olarak tanımlanan kadınların yanı sıra, 14 kadın evlilik yoluyla ${ }^{32}$, 7 kadın ise, diğer başlığı altında topladığım eğitim, kariyer vb. nedenlerle veya siyasi nedenlerle sığınmacı statüsünde Hollandaya gelen daha çok orta sınıf kadınlardan oluşan gruptur.

İlk dönemlerde aile birleşimi yoluyla gelen kadınlar da, yine başta tekstil ve gıda olmak üzere imalat sanayinin çeşitli dallarında, Hollandalı kadınların işgücüne katılım oranlarının bugünün çok gerisinde olduğu bir dönemde iş piyasasına girmeye başlamışlardı. ${ }^{33}$ Hemen her dönem, aynı yoğunlukta olmasa da Hollanda'ya bağımsız kadın göçü de devam etmiştir. Yukarıda değindiğim gibi eş ve çocukların getirilemeyeceği sınırlaması nedeniyle "misafir işçi" statüsü ile kayıtlı olarak gelen kadınların sayısı çok düşük kalsa da, bu dönemde de kayıtsız olarak çalışmak için gelen kadınlar bulunmaktaydı. Kimi görüşmeciler, Hollanda'ya 6-7 kadın arkadaş 
ya da abla-kardeş bir arada misafir işçi statüsünde Hollanda'ya gelen tanıdık ve aile yakınları olduğunu belirtmişlerdi. Ayrıca 1. nesil kadınların 4’ü Hollanda'ya bağımsız olarak gelen kadınlardı. Misafir işçilik yolunun kapandığı 70’li yıllardan sonra özellikle tekstil sektöründe çalışmak üzere bağımsız olarak gelen kadınlar bulunmaktaydı. Bu kadınların büyük bir kısmı da oturum ve çalışma izni olmaksızın, o dönemki yaygın ifadeyle "plakasız" olarak, enformel yollardan Hollanda'da iş piyasasına girmişti. Görüştüğüm kadınlar arasında, daha önce Hollanda'ya gelen akrabalarının çocuklarına bakmak için ya da "konfeksiyonda kadına ihtiyaç" bilgisi ile enformel emek piyasasına adım atan kadınların dördü de, iş bulma ve yerleşmede özellikle Hollanda'daki kadın ağlarından yararlanmıştı. 1970'li yıllarda İzmir'de Hollanda ile iş yapan bir konfeksiyon atölyesinde çalışan Filiz ${ }^{34}$, “orda konfeksiyonda çalışan Türk kadınları olduğunu duyduğu” için kocası ile ayrıldıktan sonra iki çocuğuna bakmak ve bir gelecek kurmak için tek başına Hollanda’ya gelmiştir.

Verebileceğim mücadeleyi verdim ayakta durmak için... [İzmir'de] Çalıştığım yerde makineciydim... Burda [Hollanda'da] konfeksiyonda Türk kadınları çok çalışırmış, öyle duymuştum... 40 gün içerisinde çekip geldim. 3 aylık geçici işçi statüsünde geldim. Çalıştığım yer küçük bir şehirdi. Bizim bu Ayten'in adını almıştım zaten, Amsterdam'da onu buldum... Süre dolunca Türkiye'ye dönmek istemedim. Amsterdam'a yerleştim... Bir konfeksiyon atölyesi aramaya başladım. Çocukları da getirdim yanıma. Çalışmak zorundaydım, tek ayakla koşmak zorundaydım... (Filiz, 60, 1. kuşak-bağımsız)

Dikkati çeken bir başka noktada da bugün iş piyasası dışında yer almakla birlikte özellikle 1990'lardan önce Hollanda'ya gelen görüşmecilerin hepsinin 70'ler ve 80'li yılların başlarında iş piyasasında yer alıyor olmalarıydı. Örneğin bugün refah yardımları ile geçinen ve iş piyasasına yönlendirme programları içerisinde yer alan veya "ev kadını” statüsünde olan ancak Hollanda’ya 1990 öncesi dönemde gelen kadınlar, geldikleri dönemde iş piyasasına bugünkü kadar uzak değillerdi. 1980’li yılların bu anlamda bir dönüşüme denk düştüğü söylenebilir. Küresel pazardaki şiddetli rekabet, dünya ekonomisindeki yeniden yapılanma, hizmet temelli ekonomiye geçiş, yarı-zamanlı ve geçici istihdam biçimleri ile esnekleşen çalışma biçimlerinin kadınların istihdam örüntüleri bakımından önemli sonuçları olmuştur. ${ }^{35}$ Birincil ve ikincil iş piyasaları arasındaki keskin ayrışma, bir yandan kadın emeğinin ve özellikle göçmen kadınların istihdam alanlarını genişletirken, istihdamın alışılmamış yeni biçimlerinde yoğunlaşması ve enformelleşmesi süreci ile beraber cinsiyete dayalı yeni iş piyasaları ortaya çıkmıştır. ${ }^{36}$

Araştırmaya katılan görüşmeciler açısından, 80'lerin ilk yarısı ve ikinci yarısı arasındaki dönemde dahi iş piyasası deneyimleri arasında bir farklılık olduğu görülmektedir. 1970'li yıllarda Hollanda'ya gelen Nurcan, Türkiye kökenli kadınlar açısından o dönemin çalışma hayatını tarif ediyordu:

Herkes çalışıyor, bir yerlere gidiyor, okula, işe, çoluk çocuk kimse evde değil... Fabrikaya başladım, haftada kırk saat çalışıyordum. O kırk saat çalışma işini ben 7-8 yıl yaptım. (Fabrikada) Türkiye'den getirilmiş gelinler vardı en çok. Çoğu evliydi. Hatta çoluğu çoçuğu olan çoktu... Fabrika şekerleme fabrikasıydı. Paketler yap, kaldır indir... O koşullarda çalışmak zordu gerçekten ama yine ben iyiydim, tavuk fabrikasında çalışanlar daha kötüydü. Bütün gün tavuk yoluyordu kadınlar, genç kızlar. O dönemde bizim kadınlar daha çok çalışıyordu, daha yaygındı yani. Kötü iş de olsa, temizlik fabrika işi de olsa, herkes çalışıyordu. Şeker, sakız, et fabrikaları, dokuma işi, tavuk fabrikası falan. (Nurcan, 47, 1,5. kuşak).

Cips fabrikasında çalıştım Hoofdorp'da. Ben sıcak bölümünde çalışıyordum. Daha büyükler soğuk bölümünde çalışıyordu... Sonra çamaşırda çalıştım Harleem’de. Sonra başka işler baktık... 7 sene kot işinde çalıştım. Sonra yarım güne düştüm. Kıza hamile olmadan işten çıkardılar. 2. çocuğum olduğunda 23 yaşındaydım. Büyük oğlumu işte bakıma verdik çalışacağız diye. 40 günlük kızımı Hollandalılara bakıma verdik. İşte kendi çocukları da olan aile evde bakıyordu. Bakmışlar gelen Türklerin de bebeleri oluyor. Ona bakıyorlardı 3-4 kişi... O zaman ne bileyim öyle kinderopvang'tan (kreş) falan haberim de yoktu. Yoktu zaten öyle bir şey heryerde. (Müesser, 56, 1.kuşak-evlilik göçü). 
Et ve gıda fabrikalarının yanı sıra özellikle 1970’lerin sonlarından itibaren konfeksiyon, çiçek ve temizlik işleri Türkiye'den gelen kadınların yoğunlaştığı sektörler olmuştur. Özellikle atölyelerin yanı sıra evden parça başı konfeksiyona çalışan kadınlar da vardı. Ayrıca bu sektörlerde "zwart (siyah) çalışma"37 yaygındı.

Çetin gidiyordu, sipariş alıyordu, bana getiriyordu bir sürü. Pantolonu getiriyordu işte bu böyle böyle olacak diyordu. Sonra dikip veriyordum eline. Onlar kaça veriyordu bilmem ama bana 5,5- 7,5 gulden ${ }^{38}$ veriyorlardı. Çok haklarımız gitti. (Odak grup görüşmesi)

Evde çalışmanın hiç faydası olmadı ki bize. 15 sene diktim ben evde. Eşim yardım ediyordu ben makinede. Böyle yığılıyordu artık dikişler. Benim oğlan anaokula gidip geliyordu. Gelip bir atıyordu dikişlerin, kumaşların üzerine kendini, böyle dağ gibi. Oyun yapıyordu kendine. (Odak grup görüşmesi)

1970 ve 1980’ler başlangıçta işçi kadınlar için oldukça sınırlayıcı giriş ve çalışma koşullarına rağmen, aile birleşimi yoluyla gelen kadınların da düşük ücret ve güç çalışma koşulları ile hızla iş piyasasına girmesi, Erder'in de belirttiği gibi genel olarak Avrupa'da iş piyasalarına ilişkin yapılan hesaplamaları altüst eden, beklenmedik bir gelişmeydi. ${ }^{39}$ Ancak bu dönem, tam da formel işçi göçünün sınırlandığı, iş piyasalarının daralmaya başladığı ve imalat sektörünün küçülmeye başladığı bir dönemdi. Gıda, tekstil gibi alanlarda çalışan kadınlar işlerini kaybetmeye başlamış, istihdam olanakları daha çok hizmet sektörünün alt seviyelerindeki, çamaşır, temizlik vb. alanlardaki işler ile aile işletmelerinde "ücretsiz aile emeği" ile sınırlanmıştı. Bu nedenle 1990'lar sonrasının Hollanda'sı, gençlik dönemlerinde cips, şekerleme fabrikalarında, konfeksiyon atölyeleri veyahut temizlik firmalarında tam zamanlı olarak çalışan eşler, gelinler, Hollanda'ya çalışmaya gelen kadınlar, 1,5. kuşak olarak da adlandırılan ara kuşak kadınlar için çok fazla seçenek sunmamaktaydı.

Özellikle daha ileri yaşlarda gelen ara kuşağın (göçmen ailelerin okul çağındaki genç kızları) gerek eğitim gerekse iş piyasasına giriş bakımından göç sürecinde kimi dezavantajları olduğu görülmektedir. Öncelikle başlangıçta Hollanda'daki dönemin geçici olduğu düşüncesi ile bağlantılı olarak, eğitim yaşamının görece ileri bir döneminde Hollanda'ya gelen genç kızlar, çoğunlukla annelerin çalışmasına paralel evde çocuk bakımı işlerini üstlenmişler ya da çok erken yaşlarda ve düşük ücretlerle imalat sektörünün çeşitli alanlarında çalışmaya başlamışlardır. Genel olarak vasıfsız işgücü niteliğinde kabul edilen, eğitim yaşamına Hollanda'da devam etme olanağı bulamayanlar 90'lı yıllarda hızla refah yardımlarının ve sektörünün “müşterileri” konumuna gelmişlerdi. Ayrıca 1970 ve 1980'lerin kadın merkezli alan özgürleşme politikalarının sonuçlarını vermeye başladığı ve Hollandalı kadınların yarı zamanlı bir iş piyasasına ${ }^{40}$ entegre olduğu bir dönemde göçmen kökenli kadınların bir bölümü tam zamanlı işlerinden, sosyal refah yardımlarına, yeni gelenler ise, başlangıçta bu tür sosyal güvencelerden de yoksun olarak en güvensiz çalışma alanları ya da evlere itilmiştir.

Hollanda'da küresel iktisadi dinamiklerinde etkisiyle özellikle 1980'ler sonrasında üretim, işgücü piyasası ve bölüşüm alanında yaşanan değişimler, çalışmak amacıyla Hollanda'ya farklı dönemlerde gelen kadınların geliş yolları ve deneyimlerinden de okunabilir. Hollanda'ya çalışmak amacıyla, bağımsız olarak gelen 1. nesil görüşmecilerden ikisi 1990 öncesi, diğer ikisi ise sonraki dönemde Hollanda'ya gelmiştir. Bu anlamda önce gelenlerin çalışma deneyimleri ile sonrakiler arasında önemli farklılıklar vardır. İlk grup, tekstil ve imalat sektöründe görece emek ihtiyacının sürdüdüğü bir dönemde, Hollanda’ya gelmiştir. Özellikle ilk dönemlerde gelenler, kayıt dışı çalışsalar dahi, bir süre sonra daha güvenli istihdam alanlarına erişim sağlarken, imalat sanayinin iyice daraldığı ve iş piyasasının sıkıştığı 90'lar sonrasında gelenler çok daha güç çalışma şartları ile karşı karşıya kalmışlardı. Örneğin 1990'ların başlarında Hollanda’ya gelen Nurten teyzesi kanalıyla Hollanda'ya yerleşmişti:

Teyzem 68'de gelmiş eniştemin hemen peşi sıra... Liseyi bitirdim, biz 10 kardeşiz. Ben en sondum. Dershaneye gitme imkanım olmamıştı... Burada konfeksiyonda açık olduğunu söyledi teyzem, işte kendi kızının pasaportu ile kaçak olarak getirdi beni buraya. Çalıştım bir süre turist olaraktan. Doğru dürüst bir iş bulamadım uzun süre, orda burada hep. Zaten ne kamıştı ki, kala kala bir çiçek işi (Nurten, 41, 1. kuşak- bağımsız)

Hollanda'daki Türkiyeli kadınların kompozisyonuna baktığımızda 1. kuşak kadınların bile yarısının 1980 sonrasında Hollanda'ya gelenlerden, \% 56'sının 15-45 yaş arası kadınlardan oluştuğu görülmektedir. ${ }^{41}$ Buna yine 1980'lerden sonra gelen ithal gelinleri de eklediğimizde oluşan demografik tablo ile bir arada düşündüğümüzde, göçmen kadınların neden 1990'lı yılların kaybeden tarafı olduğu daha kolay 
anlaşılabilmektedir. ${ }^{42}$ Tüm bu sosyo-ekonomik göstergelerle Türkiye kökenli kadınlar, Faslı kadınlarla birlikte yoksulluk bakımından "risk grubu" olarak tanımlanmaktadırlar.

\section{Topluluk Örgütlenmesinde Göçmen Kadınlar}

Topluluk nosyonu kadınlar için çelişkili anlamlar içerir. Bir yandan güvenlik, dayanışma ve güçlenme kaynağı iken diğer yandan Anthias ve Yuval Davis'in vurguladığı gibi özellikle yabancı düşmanı bir çevrede kadınlara verilen kültürel bütünlüğü sürdürme, kültürel ve etnik değerleri koruma ve pratik etmede görevi nedeniyle gözetim ve baskı kaynağı da olabilir. ${ }^{43} \mathrm{Bu}$ nedenle göç bağlamında kadınlar bir yandan kendi toplulukları içinde kültürel bütünlüğü koruma ve yeniden üretme görevleri nedeniyle denetim altına alınırken diğer yandan da ana toplumun hegemonik projelerinde toplumla uyumlu göçmen topluluklarının üretimi ile görevlendirilmektedir. Göçmen kadınların rolünün özgüllüğü, gerek dernekler gerekse ana toplum kurumları içinde varolma çabalarının her zaman ikili bir mücadele ile birarada yürümesinden kaynaklanmaktadır. Göçmen kadınlar Essed'in de belirttiği gibi “etnik erkeklerin" kadın varyasyonu, ya da beyaz kadınların etnik varyasyonu olarak görülmeleri nedeni ile gerek etnik temelli örgütlenmeler gerekse ana toplum içindeki özgürleşme projeleri içinde ikincil bir konumdadırlar. ${ }^{44}$ Göçmen kadınları hedefleyen proje ve programlar çokkültürcülük vurgusunun ağır bastığı dönemde etnik örgütlenmelerin, entegrasyon ve uyum vurgulu politikalar döneminde ise ana toplum refah örgütlenmelerinin öncelikleri temelinde şekillenmiştir. Bu durumun tek istisnası, çokkültürcülügün daha makro düzeyde sol siyaset çerçevesi içinde uygulandığı dönemde ortaya çıkan göçmen kadın örgütlenmelerindeki özerkleşme çabalarıdır.

Göçmenler daha başından beri, Hollanda’nın sütunlaşma mirasının sağladığı çerçevenin de yardımıyla kendi dinsel, kültürel kurumlarını oluşturma ve göçmenlere yönelik hizmetleri örgütleme yoluna gitmişlerdi. Literatürde "göçmen çokkültürcülüğü" olarak tanınan bu yapı aslında büyük ölçüde geçici olduğu düşünülen "misafir işçilerin” eve dönüşlerinde entegrasyon sorunları yaşamalarının önüne geçmek ve Jacobs'un ifade ettiği gibi daha sonraları da toplumdaki yabancı faktörünü kontrol altına almak gibi pragmatik öncüllerle hayata geçirilmişti. ${ }^{45}$ Göçmen örgütlenmeleri, özellikle aile birleşimi yoluyla diğer aile üyelerinin yeni topluma katılmaları beraberinde, göçmen topluluğun yaşadıkları toplumda karşılaştıkları kimi sorunları aşmalarını sağlamak, eğitsel, kültürel ve sosyal kimi ihtiyaçlarını karşılamak gibi önemli bir destek ve dayanışma işlevini yerine getirmişlerdi. 30 yılı aşkın bir süredir Hollanda'daki Türkiyelilerin örgütlenme süreci içerisinde yer alan Deniz'in "kendi göbek bağımızı kendimiz kesmek" olarak tanımladığı süreç, bizzat göçmenlerin Hollanda siyasal firsat yapıları çerçevesi içerisinde kendilerine yer açma çabalarının ürünü olmuştur. Dolayısıyla bugün entegrasyon tartışmalarının baş gündem maddelerinden olan Hollandaca kursları, "gönüllülük”" ya da "toplumsal katılım” gibi konular 1970'lerden itibaren göçmenlerin ve örgütlenmelerin yaşamlarında yer bulan konulardı. Bu ortamda, 70'li ve 80'li yıllarda Hollanda'ya belli bir kültürel sermaye ve eğitim bagajı ile gelen kesimler de göçmen toplulukla ilişkili aracılık görevlerine itilmişlerdi. ${ }^{46}$ Göçmenlerin örgütlenmesi süreci ile göçmenlere yönelik kurumsal sosyal hizmetin örgütlenmesi süreci birbirini besleyen ve zorunlu olarak birbiri ile iç içe geçen bir süreçti. Değişen siyasi ortam, ana toplumun göçmenlere yönelik politika alanını genişletmesi ve bu alanın farklılıkların yönetimi için farklı aktörlerin müzakeresine açık hale gelmesi göçmen örgütlenmelerini de etkilenmiştir.

Dernekler, kuruldukları dönemde tipik erkek alanlarıydı ve kadınların sorunlarına yer açmaya yönelik çabalar dernek içerisindeki erkek egemenliği ile mücadeleyi gerekli kılıyordu. Çokkültürcü politikalar beraberinde "öz-örgütlenme" ${ }^{47}$ sürecinin kurumsal bir devlet sübvansiyonu sistemi ile bütünleşmesi ve devletle örgütler arasında kurulan klientalist ilişkiler, topluluk içinde etnik bir elit yapısının oluşmasına zemin hazırlamaktadır. ${ }^{48}$ Devletle kurulan klientalist ilişkiler ve bunun ürünü olan elit yapısı kadınların göçmen örgütleri içinde geri planda kalmalarına yol açan nedenlerden biri olarak görülebilir. ${ }^{49}$ Dernek işinin, yerel ve ulusal yönetimlerden alınacak sübvansiyonlar ve "göçmen" bürokrasisi ile ilişkilere bağlı olması bu işin "uzmanı" olan kişilerce yürütülmesi düşüncesini pekiştirmektedir.

Aslında kadınlar başlangıcından beri topluluk örgütlenmelerinde yer almaktaydılar. Göçmen dernekleri içerisinde kazanılan deneyimler özellikle göçmenlere yönelik politika ve sosyal hizmet alanlarının oluşmasında etkili olmuştu. Paradoksal bir biçimde, derneklerin büyük harfli siyaseti bakımından ikincil bir konumda olmak, kadınların ana toplumun sosyal sektörü ile ilişkili bir alanda deneyim kazanmalarına yol açmış görünmektedir. Essed de, etnik azınlık kadınların etnik örgütlenmeler içerisinde lider konumlarından uzakta olmalarının onları etnik milliyetçilik ve diğer etnik örgütlenmeler karşısında rekabetçi duygulardan bir ölçüde daha uzak durabildiklerini belirtmektedir. ${ }^{50}$ Göçmen örgütleri içerisindeki deneyim, göçün ilerleyen 
zamanlarında, bu alanda aktif roller üstlenen kadınların ana toplumun eğitim, refah, sosyal hizmetler gibi alanlardaki çeşitli kurumlarında da varlık göstermelerine ve seslerini duyurmalarına vesile olmuştu. Diğer yandan da bu örgütlenme deneyimi, Hollanda kadın hareketi içerisinde varlık gösterme mücadelesi ile de paralel yürümekteydi.

\section{Göçmen Kadınların Mirası: Hollanda Türkiyeli Kadınlar Birliği (HTKB) Örneği}

HTKB 1974 yılında, Hollanda Türkiyeli İşçiler Birliği ${ }^{51}$ (HTİB) bünyesinde yer alan kadınların girişimiyle kurulmuştu. HTKB genel bir çatı örgüt olmakla birlikte, özellikle çeşitli mahallelerdeki semtevleri kanalıyla yerel faaliyetler örgütlemeyi başarabilmiş, "TKP'li kadınlar"52 olmanın dışında, göçmen kadınları bünyesine katmak ve farklı kesimlere ulaşmayı hedeflemiştir. Dolayısıyla Türkiye'deki siyasal gündeme yönelik, Türkiye'deki demokratikleşme mücadelesine destek vermenin yanı sıra, göçmen kadınlara yönelik faaliyetlerin oluşumunda da önemli rol oynamıştır. Ayrıca 1979 yılından itibaren 10 yılı aşkın bir süre 3 ayda bir "Kadınların Birliği" (Turkse Vrouwenkrant) adı altında Türkçe ve Hollandaca olarak iki dilde yayın yapan bir dergi çıkarılmıştır. Görüşme yaptığım kadınlar arasında, o dönem HTKB'de aktif olan ve göçmen işçilerin eşleri veya kızları olarak Hollanda'ya gelen kadınlar bulunmaktaydı. Kendisi veya ailesi işçi kökenli olan bu kadınlar, siyasal sığınmacı olarak Hollanda'ya gelen TKP kökenli kadınlar ile bir arada çalışmalar yürütmüşlerdir. HTKB $\operatorname{arşivinin~}^{53}$ envanterini çıkaran ve Uluslararası Sosyal Tarih Enstitüsü'ne devredilmesini sağlayan Özdoğan diğer Avrupa ülkelerine kıyasla Türkiyeli kadınların Hollanda'da erken dönemde böylesi bir örgütlenme deneyimini yaşamış olmalarının dikkat çekici olduğunu belirtmektedir. ${ }^{54}$ Merkezi Amsterdam olan örgütün Nijmegen, Den Haag, Rotterdam ve Leiden'da da şubeleri bulunmaktayd $1 .{ }^{55}$

HTKB, yirmi yılı aşkın bir süre, Amsterdam merkez olmak üzere Hollanda genelinde faaliyetlerine devam etmiş tek göçmen kadın örgütüdür. Özellikle 1980'li yıllarda kadın özgürlüğü konusunda etkin bir politika izlemiş ve Hollanda kadın hareketi ile işbirliği çabasında olmuştur. Ayrıca Türkiye kökenli göçmen kadınların Hollanda'da varlık göstermeye başladığı görece erken bir dönemden itibaren mahalle ve semt düzeyinde faaliyetler örgütlemesi, Hollanda'daki göçmen kadınlar açısından çok önemli bir deneyim birikimi yaratmıştır. Örneğin semtevlerini (buurthuis), göçmen kadınlara ve göçmen kadın faaliyetlerine açılması konusunda ilk adımlar HTKB döneminde atılmış ve sonrasında yaygınlık kazanmıştır. ${ }^{56}$ HTKB, özellikle o dönemlerde Hollanda'ya aile birleşimi yoluyla gelen kadınların ve genç kızların eğitim yaşamına yönlendirilmesi, dil eğitimi almaları ya da çeşitli becerilere yönlendirilmesi konusunda önemli çalışmalar yürütmüştü. Çeşitli semtlerde kadınlara ve genç kızlara yönelik olarak Hollandaca kurslarından, bilgisayar ve Türkçe kurslarına, dikiş kurslarında sağlık toplantılarına pek çok alanda eğitim faaliyetinde bulunmuştur. Hollanda'da göçmenleri ilgilendiren konular, çıkarılan yasalar kamuoyundaki tartışmalar konusunda da kadınlara yönelik bilgilendirme toplantıları düzenlemiştir. Kadınlara yönelik özel konuşma saatleri oluşturularak, göçmen kadınların oturum hakkından, iş piyasasındaki sorunlara, sağlık ve çocuk bakımı konusundan, eğitim alanındaki sorunlarına kadar pek çok alanda destek sağlanmaya çalışılmıştır. Aslında semtevleri kısa bir dönem, 1960’lı ve 70'li yıllarda Hollanda kadın hareketinin de örgütlenme zeminlerinden biri olmuştu. Günümüzde sosyal refah sektöründe yer alan üçüncü sektör kuruluşlarının faaliyet alanları olarak beliren bu mekanlar, çeşitli ara dönemlerde kadın hareketlerinin mobilize olduğu, gündelik “dertlerin”, eşit haklar ve yurttaşlık mücadelesinin konusu haline gelmesine zemin hazırlayan mekanlar olarak kullanılmıştır. Tam da Hollanda kadın hareketinin 1980'lerde, sol hareketle bağlarının kopması ve giderek çeşitli idari mekanizmalar içerisinde yer alması ile sonuçlanan bir kurumsal zemin kazanma süreci içerisinde, profesyonelleşmiş örgütlenmelerde konsolide olduğu dönemlerde, göçmen kökenli kadınlar, HTKB örneğinde gördüğümüz gibi, bu merkezleri kullanmaya ve faaliyetlerde bulunmaya başlamıştır. 


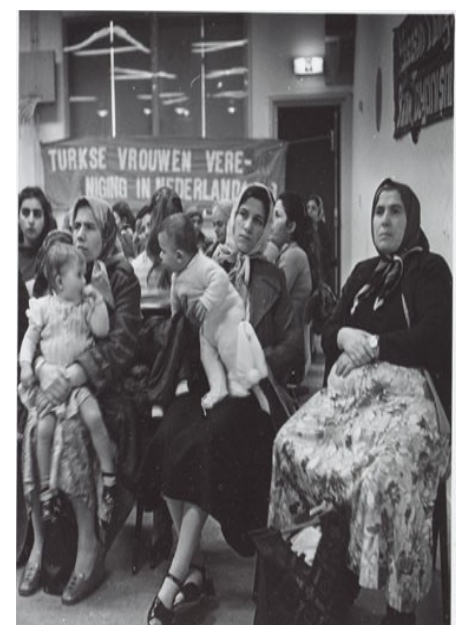

Göç ve Yurttaşllk

HTKB'nin semtevi Oosterhonie'deki(?) 8 Mart Kutlaması, Amsterdam 1982

Foto: IIAV Arşivi, A. Vaillant

HTKB deneyimi, kadınların ana toplumun çeşitli kurumlarında da varlık göstermeleri ve güçlenmeleri için de önemliydi. HTKB, örneğin, annesi ve kardeşleri ile birlikte 70'li yıllarda aile birleşimi ile yolu ile 15 yaşında Hollanda'ya gelen ve erken yaşta şekerleme fabrikasında çalışmaya başlayan Nurcan'ın hayatında hem bir okul, hem de başka alanlara geçiş için önemli bir sıçrama noktası olmuştur. Hollanda kadın hareketi ile daha yakından ilişsi içine geçtiği emanncipatiebureau'larda (özgürleşme büroları) çalışmaya böyle bir deneyimden sonra başlamıştır. Nurcan, HTKB kanalıyla yaşadığı değiş̧imi şu sözlerle anlatıyordu:

HTKB'li kadınlar aracılı̆̆ıyla -ki o dönem bayağı aktifti kadınlar da- pek çok kişi ile tanıştım. Çiler'le tanışıım mesela. O, nasıl desem sana, ben bugün Nurcansam, gelmiş olduğum yerde onun çok emeği vardır... O dönem HTKB'nin Türkiyeli kadınlara yönelik bir tercüman yetiştirme projesi vard. ${ }^{57}$ Genç kılar içindi özellikle... Neyse HTKB'nin desteğiyle o sınava katıldım ve kazandım. Fabrikaya gittim, dedim ben gidiyorum... O dönemde göçmenlere bakış açısı, göçmenler bi şey yapamaz, fabrikada çalışır ancak idi. Mümkün değil gidemezsin, iki ay ihbar süren var dendi. Dedim kusura bakmayın, okula gidiyorum, hayatımı değiştiriyorum, işimi değiştiriyorum! (Nurcan, 47, 1,5. kuşak).

özetlemekteydi:

Örgütün kurucu kadrosunda yer alan bir başka görüşmeci de, o dönemki faaliyetleri şu şekilde

HTKB'yi kurduğumuz dönem, başlarda en fazla dört beș kişiydik. Politik akımdan gelen iki kişiydik biz zaten. İlk zamanlar yer olmadığı için, Türk Kültür Merkezi’nin yerinden de yaralanıyorduk. Hatta sağ kesimin örgütlendiği yerdi bu ama biz kadınlar için orada da çalışmalar yapıyorduk. İlerleyen yıllarda Hollandalı kadınlarla bir dayanışma komitesi oluşturduk. Onlarla birlikte Hollandaca kursları düzenledik... Biz hiç HTï'in binasında çalışma yürütmedik. Genelde Buurthuis'larda falan çalışmalar yürütüyorduk... Çok çeşitli kadınlar geliyordu çalışmalarımıza.

Hollanda'daki Türkiyeli kadınlar da 1980'lerde gerek sosyal akademilerde gerekse sosyal hizmet uygulamalarında etnik azınlık kadınlara yönelik bakışı ve egemen normları eleştirerek, kendi ses ve deneyimlerini bu kurumlara taşımışlardı. Ayrıca faaliyetlerinin örgütlenmesinde göçmen dernekleri yerine semt evlerini kullanarak hem dernekler içerisindeki iktidar ilişkilerinden kurtulmak hem de tabandaki kadınlar için bir güçlenme ve dönüşüm alanları yaratmaya çalışmışlardı. 12 yaşındayken aile birleşimi yolu ile annesi ile birlikte Hollanda'ya gelen İlkay, sosyal akademiye ${ }^{58}$ başlamadan önce ve sosyal akademiye devam ederken HTKB'de yürüttüğü faaliyetler aracıllı̆ıyla deneyim kazanmıştır:

O dönemde $H T K B$ 'ye gitmeye başladım... Orada bir şeyler alabileceğini ve verebileceğini öğreniyordun. Çok eksiklik, çok ihtiyaç vardı. Sorunları apaçık görüyorsun. O şekilde sosyal akademiye başladım... Okulda bir grup oluşturduk. Siz sosyal akademiden 
bahsediyorsunuz ama bizim istediğimiz, bizim çalışmak istediğimiz alana uygun dersler, teoriler falan yok dedik. Materyal geliştirdik, konuklar falan getirmeye başladık, tartışmalar düzenledik. Başka akademileri inceledik, örnekler aradık falan. Akademi yılları hep bir mücadele ile geçti. Bir dönem bu dil, iki dillilik meselesi beni çok ilgilendiriyordu... Şimdiki teoriler yoktu o zaman sosyal akademide. Bize gösterilmiyordu, ne bileyim çocuk anadilini iyi bildiği zaman ikinci dili de daha iyi öğrenebileceği falan bilinmiyordu. Hollanda'da yoktu yani. Ben o zaman araştırdığımda, o teorilerin çoğu İngiltere'de, Amerika'da falan geliştirilmişti. (İlkay, 49, 1,5. kuşak).

Göçmen derneklerinde ve genel olarak topluluk örgütlenmesinde edinilen deneyim, göçmen kadınlar için sosyal hizmet alanının gelişimi ve günümüzdeki entegrasyon ve refah sektörünün altyapısının kurulmasında etkili olmuştu. Özellikle 80'lere kadar olan dönemde aile birleşimi veya bağımsız yollarla Hollanda'ya gelen kuşak gerek Hollanda'daki çalışma deneyimi, gerekse siyasi ve sosyal hareketlilik açısından 80'ler ve sonrasında gelenlerden kimi farklılıklar gösteriyordu. Bu farklılık bir önceki kuşağın iş piyasasının görece açık, siyasi ve sosyal hareketliliğin görece canlı olduğu bir siyasal ve iktisadi atmosferde, "çokültürcü” politikalara eşlik eden yeniden bölüşümcü bir paradigmanın etkisi altında bulunduğu bir Hollanda'da bulunuyor olmaları ile açıklanabilir. Özellikle günümüzdeki göçmenlere yönelik sosyal sektörün biçimlenmesinde bu kuşak kadınların gerek dernek ve sendikalar içinde gerekse diğer kanallardan edindikleri deneyimin önemli olduğunu görüyoruz. Her şeyden önce bu kuşak kadınlarda sosyal hareketliliğe ilişkin umutların daha canlı olduğu söylenebilir. Uzun y1llar farklı göçmen semtlerinde kadınlara yönelik projelerde çalışan Handan, semtlerdeki kadın örgütlenmesi ve dil kurslarının daha 1970'li yıllarda bizzat kadınların girişimi ile oluşturulduğunu anlatmıştı:

Mesela buradaki dil okullarının temeli atılırken orada da bir grup Türk kadını vardır esasında. Ta 1970'lerde wolvassen educatie (yetişkin eğitimi) birimini ilk kuranlar da Amsterdam Belediyesi içindeki Türk kadınları. Daha sonra bunlar ROC'nin ${ }^{59}$ dil bölümlerine dönüştürüldü. İşte bu semtevlerinde falan kurslar vardı. Kadın çalışmasının temeli orada atıldı. Daha sonra Amsterdam'ın pek çok yerinde uygulandı. (Handan, 56, 1. kuşak).

\section{Hollanda Kadın Hareketi ve Göçmen Kadınlar}

Özellikle 1980'li yıllarda, göçmen kadın gruplarında çeşitli faaliyetler yürüten kadınlar, Hollandalı kadın hareketi ile de ilişki kurmaya başlamışlardır. Görüşmeciler arasında Hollanda kadın örgütleri içerisinde, kürtaj hakkından, evli kadınlara da eğitim ödeneği hakkı, eviçi emeğin tanınması ve eşit bölüşülmesi mücadelesinden, iş hayatındaki eşitsizliklere kadar hemen her alanda aktif bir biçimde katılan kadınlar bulunmaktaydı. Özellikle 1970'ler ve 80’ler diğer pek çok Avrupa ülkesinde olduğu gibi, dönemin siyasal firsat yapılarının da etkisiyle Hollanda kadın hareketinin önemli kazanımlar elde ettiği bir dönemdi. Her ne kadar feministler için "altın yıllar" da olsa, göçmen ve renkli kadınlarla, yerli Hollandalı kadınlar ve örgütler arasındaki dayanışma düzeyi sınırlı bir düzeyde kalmıştı. Essed, ötekileştirme, etnikleştirme ve 1rkçılığı Hollanda kadın hareketi içerisindeki çatlağın nedeni olduğunu ileri sürmektedir. ${ }^{60}$ Nitekim görüşmecilerden Lale'nin kadın örgütleri içindeki konumuna ilişkin aktardıkları, bu dayanışmanın niteliğine ilişkin ipuçları vermekteydi:

O ilerici dönemlerde Hollandalı arkadaşlarım da çoktu. Şimdi onların da bizimle görüşme temelleri ortadan kalktı. Talepleri de azaldı. O dönemde onlar dünyaya açıktılar. Bizden çok şey öğrendiklerini söylüyorlardı. Dünyaya açılıyorlardı. Ama nedense bilmiyorum, gel beraber gidip şuradaki ayakkabıcıya yeni modeller gelmiş bakalım olmuyordu (Lale, 55, mülteci).

Hollandalı kadınlarla birlikte özgürleşme bürolarında çalışan Nurcan ve kadınların özgürleşmesine yönelik olarak oluşturulan yerel kurumsal mekanizmalarda çalışmış olan İlkay da, o dönemki faaliyetlerini şu şekilde ifade ediyordu:

Kadınların gelişmesi, eşit haklar, kadın meseleleri konusunda çalışan bürolardı bunlar...

Sadece iş bulma değil, çok ilginç projeler yapardık. Kadınların hukuksal sorunlarından tut da, toplumsal sorunlarına kadar her konuda çalışırdık... Amaç Hollandalı ya da göçmen tüm kadınları örgütlemekti. Ben zaten bu örgütleme işinde yıllarca çalıştım. Maaşlı çalıştığım iş dışında gönüllü olarak da Türk çevrelerinde falan, özellikle HTKB'de 
çalıştığım yıllarda, neredeyse hiç uyumadan işime gittiğimi hatırlıyorum... Hollandalı kadın hareketi ile de çalıştık. Mesela bağımsız oturum hakkı konusunda çok çalıştık -ki biliyorsun hala tam olarak alınamamış bir haktır... 10 yıldan sonra, belediyeye geçtim. Çünkü o bürolar kapandı yavaş yavaş. 'Kadınlar geliştiler, artık özel bu tür büroların çalışmasına gerek yok' dendi. (Nurcan, 47, 1,5. kuşak)

(Hollanda feminist hareketi) 60'larla Dolle Mina ile başlamış. Tabii biz o dönemi pek yaşamadık. Biz göçmen kadınlar olarak 80'leri yaşadık Hollanda'da. Orada da "beyaz kadınlar", "Hollandalı kadınlar" olarak varlardı. Aralarında tabii gerçek dostlarımız da vardı. Ancak çoğu kendi düşündükleri veya çalıştıkları sistemde bize teklifte bulunuyorlardı. Yabancı kökenliler olarak, biraz ne derler hamilik falan oluyordu. Biz çok geçmeden dedik hayır o sizin gelişmenizdir, biz olayları başka görüyoruz dedik. O dönem zaten, bir sürü öz-örgütler kurulduğu gibi kadın örgütleri de gelişti. Değişik yaşlara değişik gruplara hitap eden çalışmalar başladı. Bu gelişmeleri Hollanda'ya sokmaya çalıştık. (İlkay, 49, 1,5. kuşak)

Örgütün kurucu kadrosunda yer alan bir başka görüşmeci, diğer Türk örgütlerinden farklılıklarını siralarken bu noktalara vurgu yapıyordu:

Bizde bir de şöyle bir şey vardı: HTKB aslında Amsterdam Belediyesinden fon alıyordu ama biz Amsterdam'dakinin üzerine bir de ülke çapında bir örgütlenmeyi de görev edinmiştik. Biz tek göçmen kadın örgütüydük. Sadece Türk olarak değil bütün göçmen kadınların sözcülüğünü yapmak gibi bir durumdaydık da... Hepimiz gönüllü çalıştık örgütte... Bizim örgütlenme biçimimizde başlangıçta pozitif olan bir şey de, hep Hollandalılarla işbirliği düşüncesiydi. Kendi kendimize yapalım Hollanda’ya karşı yapalım değildi. Haklarımızı savunuyorduk ama hep de bir işbirliği yapalım bilinci vardı. (Deniz, 59,1 . kuşak, bağımsız )

HTKB döneminde kadınlar Hollanda kadın hareketi ile dirsek temasını kaybetmemek ve bunu gerçek bir işbirliğine dönüştürmek, diğer yandan da örgüt tabanında "Hollandalı feministler"e yönelik olumsuz bakışı kırmak için de çaba sarf ediyordu. Örneğin 1983 yılında Texel'de yapılan örgüt içi eğitim toplantısındaki tartışmalar sonrasında hazırlanan raporun diğer kadın örgütlerine yönelik bölümünde bu konuda özeleştiri yapiliyordu:

Bizler çoğu kez Hollandalı kadınları 'feminist' olmalarından ya da birlikte yaptığımız çalışma/eylem sırasında bizleri yönetmeye çalıştıklarından yakınırız. Sık sık onların yabancı kadınlar konusundaki çalışmalarını eleştiririz... Bizlerle birlikte, bize dönük eylemlerde ancak bizim şartlarımızla yer alabileceklerini söyleriz. Tüm onlardan beklediklerimizi, her türlü yazma, hazırlık, randevu, teknik gereçleri ayarlamalarını ama yapılan işin içeriğini bize bırakmalarını isteriz. Bu dayanışma mıdır? ${ }^{61}$

HTKB’nin Türkiyeli kadınlara dönük özeleştirisi ve Hollandalı kadın hareketi ile bir arada, eşit bir ortaklık hedefine rağmen, bu tarz bir ortaklık ve dayanışmanın önünde önemli engeller olduğu, göçmen kökenli kadınlarla Hollandalı kadın grupları arasında ilişkiye damgasını vuranın bir "kurtarma" misyonu olduğu anlaşılmaktadır.

Gerçekten de, dönemin kadın örgütlenmesi hem Hollanda kadın hareketi hem de diğer göçmen kadınlarla bir arada bir çalışmanın yürütülmesi için çaba sarf etmişti. Bunda elbette HTKB'nin TKP ve Türkiye'deki İKD ile ilişkileri ve dünyada sol hareketin uluslararası perspektifinin de rolü büyüktü. Ancak yine de yerel düzeyde farklı gruplarla müzakere etmek durumunda olan kadınlar bu alanda bulundukları yerin koşulları ve farklı gruplarla ilişkilerin dinamiği içerisinde deneyim kazanmışlardı. Örneğin daha 1980’lerin başında, Hollanda'daki Türkiye, Fas, Portekiz, Yunanistan, İspanya ve Surinam kökenli kadınların katılımı ve HTKB'nin girişimi ile örgütlenen Yabancı Kadınlar Kongresi ya da 1985'teki BM Uluslararası Nairobi Kadın Konferansı'na Avrupa çapında bir Türkiyeli Göçmen Kadınlar Delegesi oluşturma yolunda yürütülen çabalar kayda değerdir. Bu amaçla başta Hollanda ve Almanya olmak üzere, çeşitli Avrupa ülkelerinde yaşayan Türkiye kökenli kadınların katılımı ile 6-8 Haziran 1985 tarihinde Amsterdam'da gerçekleştirilen “Türkiyeli Göçmen 
Kadınlar Avrupa Konferansı" sonuçları 1985 Nairobi Konferansı'na taşınmış ve Amsterdam'da örgütlenen bu konferans yoluyla, Nairobi'de Göçmen ve Siyah Kadınlar delegasyonu oluşturulmuştur ${ }^{62}$. Hendessi, dünya çapında 14.000 kadının yer aldığı böylesi kapsamlı bir Konferans'ta BM ve BM'nin desteklediği uluslararası kuruluşların göçmen ve mülteci kadınlarla ilgili pek çok tartışma ve atölye düzenlemekle birlikte genelde konuşmacıların göçmen ve mülteci topluluklardan gelmediğini ve bu tartışmalarda da göçmen ve mülteci kadınların onları kurtaracak bir aracıya muhtaç zavallı ve pasif kimseler olarak resmedildiğini belirtmektedir:

$\mathrm{Bu}$ oturumları örgütleyen Dünya Kiliseler Birliği göçmen ve mülteci kadınların kendi örgütlenmelerini yok saysa da; neyse ki göçmen ve mülteci kadınlar Forum'a delege gönderip, kendi seslerini ve taleplerini duyuracak çeşitli atölyeler oluşturmuşlardı. ${ }^{63}$

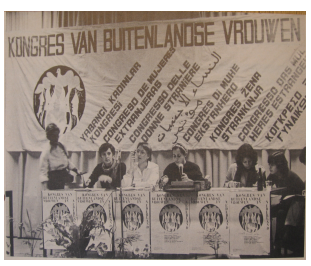

27 Eylül 1981 Tarihinde Amsterdam'da gerçekleştirilen Yabancı Kadınlar Konferansı, Kadınların Birliği Dergisi No: 11, Kasım Aralık 1981 [IISH Arşivi]

şte bu delegelerin içerisindeki bir grubu da Hollanda'dan katılan ve Avrupa'daki göçmen ve mülteci kadınların sorunlarını Nairobi’ye taşıyan Türkiyeli kadınlar oluşturuyordu.

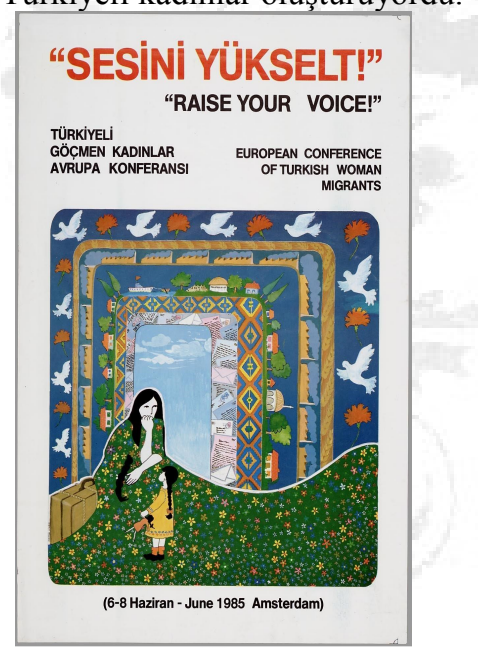

Türkiyeli Göçmen Kadınlar Avrupa Konferansı Afişlerinden bir örnek [IIAV Arşivi-A997]

1998 yılında kadın örgütleri, Hollanda kadın hareketi için dönüm noktalarından biri olarak kabul edilen 1898 tarihli Kadın İşgücü Sergisi’nin yüz yıl dönümünde “Kadın ve Çalışma 1898-1998” başlıklı çeşitli sergi, konferans, gösteri ve yayın faaliyetleri örgütlemişti. HTKB ve göçmen kadın hareketinin önde gelen isimlerinden Özden Yalım, 1998 faaliyetleri ile ilgili olarak göçmen kadınların ve onların işgücüne olan önemli katkısının yıl boyunca süren bütün tartışma ve programlardan bütünüyle dışlandığını belirterek, Hollanda kadın hareketinin halen kendi kara noktaları ile hesaplaşmasını gerçekleştirmediğini ifade etmektedir. ${ }^{64}$ Oysa Hollanda'da kadınların işgücü piyasasına katılımının bugünlerin de gerisinde olduğu bir dönemde göçmen kadınlar, tavuk-et, şekerleme vb. gibi gıda fabrikalarında, tekstil atölyelerinde, çiçek seralarında yoğun olarak işgücüne katılmaktaydı. Bugünün özgürleşme politikalarında resmedildiğinin aksine, kadınlar "kültürleri nedeniyle" evde kalmayı seçmiyorlardı. Küresel iktisadi dinamikler, değişen istihdam yapısı ve iktisadi dengeler, yerleşik göçmen kadınları büyük ölçüde iş piyasasının dışına itmekteydi. Hollanda kadın hareketi içerisindeki bu tür "kör noktalar", göçmen kadınlarla ilgili özgürleşme ve entegrasyon politikalarına ilişin kamusal tartışmalarda da sıklıkla kendini göstermektedir. Bir görüşmecinin HTKB deneyimine ilişkin bu görünmezliğe ve haksızlığa işaret ettiği gibi, Hollanda' da yaşayan kadınlar iş piyasasında, yurttaşlık mücadelesinde yer almışlardı: 
Adları olmayan onlarca kadın var. Mesela Perihan Hanımdan kim söz eder? Sakız fabrikasından çıkıp, çocukları ile semtevine koşan kadınları, ilk kez greve giden göçmen kadınları... Kadriye Hanım’ı kaç kişi tanır ben merak ediyorum. 1963 yılında kocası ile bir çocuğunu bırakıp Almanya üzerinden kalkıp buraya gelmiş. İşte bu kadın hala burada yaşıyor. (Handan, 56, 1. kuşak).

Bu deneyimi yaşayan pek çok kadın, kurumsal mekanizmalar içerisinde de yer alarak Hollanda sosyal refah sektörünün dönüşümünde rol oynamıştır. Ancak toplumsal cinsiyetin yalnızca kadınlarla, etnisitenin ise yalnızca etnik azınlıklarla ilgili olduğu yönündeki egemen anlayış, bir görüşmecinin çok net bir ifadeyle belirttiği gibi, göçmen kadınların “ortadaki boşluğa düşmelerine”, her iki politika alanın da öznesi olarak görülmemelerine yol açıyordu.

\section{Sonuç Yerine...}

İş piyasasının yanı sıra sosyal ve siyasal aktivizm, yurttaşlık mücadelesi açısından baktığımızda da, günümüz Hollandasındaki "göçmen kadın" sterotiplerinin dışında, kendi hayatları üzerinde fail olmanın yanı sıra, yurttaşlığı biçimlendiren gündelik yaşam alanındaki mücadelelere dahil olan farklı göçmen kadınlık deneyimleri ile karşılaşıyoruz. 1970'li yıllardan itibaren yaklaşık 20 yıllık bir süreçte HTKB'li kadınlar, farklı göçmen kadın kesimlerinden beslendiği ve faaliyetlerini tabana yaydığı dönemde gerek göçmen örgütlenmelerine (kendi içinden çıktığı siyasal çizgi de dahil) gerekse Hollandalı kadın hareketine karşı eleştirel bir mesafe imkanını kısa bir süreliğine de olsa yakalamış ve özgürleşme için açılan imkanları kullanma çabasına girmiştir. Ancak bu deneyim, gerek göçmen dernekleri içinden gerekse Hollanda kadın hareketinin perspektifinden yok sayılmış, HTKB'li kadınlar farklı etiketlerle, "HTïB'lilerin eşleri”, "entelektüel kadınlar", "siyasiler" olarak damgalanmıştır. Oysa HTKB'nin bir dönem göçmen kadınlar için önemli bir okul haline gelmesine sebep olan dinamik kadınların yaşamlarındaki "yakıcı” sorunlarla kurduğu bağlantı olmuştur. Gerek "etnik" örgütlenmeler gerekse kadın hareketi içerisindeki deneyimleri olan Türkiyeli kadınlar, her iki politika alanındaki egemen çizgileri sorgulamaya başlamışlardır.

Göçmen kökenli kadınlar 80’li yıllar ve 90'ların başında kadın eşitliğine yönelik kurumsal mekanizmalar içerisinde yer almaya başlamış ve "seslerini” bu platformlara taşımışlardır. Ancak 1990'lardan sonra Hollanda'da kadın özgürlüğüne yönelik olarak kurulan özel birimler kaldırılmış, kadın sorunu da "göçmenlerin entegrasyonu" çerçevesi içerisinde göçmen kökenli kadınların "kurtarılması" sorununa indirgenmiş görünmektedir. Bir topluluk ve problem kategorisi olarak göçmen kadınların dramatize edilmesi, siyasaların oluşumu ve uygulanması sürecinde de etkili olmaktadır. Özellikle 2000'li yıllardan itibaren kamuoyunda ve medyada tartışıldığı yönleriyle "Müslüman kadınlar meselesinin” yoğun bir proje alanı haline geldiğini görüyoruz. Bu politikaların çerçevesini çizen neoliberal yurttaşlık nosyonu özellikle "refah bağımlısı göçmen kadın” tipini ön plana çıkarılmasında etkilidir. Toplumsal cinsiyet eşitliğine ihtiyacı olan grupların Müslüman kadınlara indirgenmesi ve grubun giderek homojenleştirilerek, problem kategorisi haline getirilmesi, grubun içindeki direnişleri ve değişim çabalarını görmezden gelir. Ayrıca göçmen kadınların sosyal, ekonomik, eğitsel konumları arkasındaki yapısal faktörleri ve iş piyasası, eğitim ve toplumsal yaşamdaki ayrımcılıkların da üzerini örten bir bakış açısıdır bu. Göçmen kadınlar bütünüyle geri kalmış, kültürlerinin ve geleneklerinin kurbanları olarak tanımlandıklarında, grubun bütün üyeleri için oluşturulan politikalar minimum bir özgürleşme projesi sunmaktadır.

Yurttaşlık yasal bağlam ve haklarla ilişkili bir şey olmasının ötesinde, aile, sağlık, sosyal yardım ve refah gibi gündelik yaşamın örgütlendiği alanlarda her gün yinelenerek yaşanan müzakere ve mücadelelerle de şekillenen bir aidiyet forumu olarak farklı bağlamlarda harekete geçirilebilen dinamik bir sürece işaret eder. Toplumsal adalet düşüncesi ve eşitlikçi paradigma ile kurulan bağlantı, gündelik yaşamdaki mücadelelerden beslendiği ve bu mücadelelerle ilişkili olduğu ölçüde dönüştürücü bir etki yapabilir. Diğer taraftan neoliberal dönemin, hak ve adalet temelli nosyonlar ile bağlantısı koparılmış bir faillik ve özerklik tasarımı, yurttaşlığı apolitik bir biçimde belli donanımların kazanılmasına (dil öğrenmek, kendine bakabilmek, çalışmak vb.) indirgemekte, bu norma uymayanları "ehil olmayan” yurttaşlar olarak problematize edilmesine yol açmaktadır. Hollanda'da 1990'lardan sonra egemen olmaya başlayan ve özellikle entegrasyon, özgürleşme gibi politikaları belirleyen çerçeve içerisinden "göçmen kadınlar", yeniden bir "sorun" olarak tanımlanmaktadır. 
${ }^{1}$ Öyle ki, örneğin Portekiz'de 1989'a kadar kadınlar için pasaport çıkarılmıyor, kadınların eşlerin (veya babaların) pasaportuna bağlı olarak seyahat etmesi bekleniyordu. Bu düzenleme değiştikten sonra dahi, evli kadının yurtdışı seyahati kocanın iznine tabiydi. Pek çok Avrupa ülkesinde de bu durum uzunca bir dönem varlığını korumuştu. Sarah J. Mahler ve Patricia P. Pessar, "Gender matters: ethnographers bring gender from the periphery toward the core of migration studies", International Migration Review 40, no. 1 (2006), 39-40.

${ }^{2}$ Mirjana Morokvasic, "The overview: Birds of Passages are also Women”, International Migration Review. Women in Migration. Special Issue 18, no. 4 (1984): 886-907.

${ }^{3}$ Göç literatüründe önemli bir yer olan kimi göç araştırmalarında yalnızca göçmen erkeklerle yapılan anket ya da görüşmelere ya da göçmen erkeklere eşleri veya kız çocukları ile ilgili sorulara verdikleri cevaplara dayanarak, bütün göçmen nüfusa ilişkin sonuçlara ulaşılmaktaydı. Bu nedenle ilk aşama kadınlara göç araştırmalarında yer verilmesi olmuştur. Bkz.

Pierrette Hondagneu-Sotelo, "Gender and Immigration. A Retrospective and Introduction", der. P. Hondagneu-Sotelo \& C. Cranford (der.), Gender and U.S. Immigration: Contemporary Trends, (California: University of California Pres, 2003): 5; Mahler ve Pessar, "Gender matters,", 28.

${ }^{4}$ Sema Erder, "Uluslararası Göç Sürecinde Kadının Gündeme Gelişi ve 'Getto'daki Kadın”, Refah Toplumunda Getto (İstanbul: İstanbul Bilgi Üniversitesi Yayınları, 2006), 301.

5 “Küresel bakım krizi”, “yoksulluğun kadınsılaşması” gibi adlarla anılan, küresel kapitalizmin dinamikleri ile bağlantılı olarak ortaya çıkan hemşireler, çocuk bakıcıları, ev içi hizmetler, seks emekçileri, kadınların bağımsız olarak katıldığı göç türlerinin artması nedeniyle "göçün kadınsılaşması" olgusuna yönelik ilginin artmasına yol açmıştır. Stephen Castles ve Mark J. Miller, The Age of Migration, International Population Movements in the Modern World (London: Palgrave Macmillan, 1993).

6 Eleonore Kofman, "Female' birds of passage'a decade later: Gender and immigration in the European Union" International Migration Review 33, no. 2 (1999), 270.

${ }^{7}$ Freeman, Avrupa bağlamı ile ilişkili olarak erkeklerin göç alan ülke açısından daha büyük bir tehdit olarak görülmeleri nedeni ile de bağımsız kadın göçünün tam olarak belgelenemediğini ileri sürmektedir. Jane Freedman, Gender and Insecurity: Migrant Women in Europe (Aldershot\&Burlington: Ashgate, 2003).

${ }^{8} \mathrm{Bu}$ araştırma bağlamında Amsterdam'daki Türkiye kökenli kadınların göçmen mahallelerindeki gündelik yaşam deneyimleri, etnik örgütlenmeler, göçmenler için çeşitli hizmetler sunan sosyal refah örgütlenmeleri, entegrasyon politikaları ve yurttaşlık teknolojilerinin bir arada yer aldığ bir kurumsal bağlamın analizi için giriş noktası olarak alınmaktadır. Feminist yöntemsel yaklaşımlardan beslenerek oluşturulan nitel alan araştırmasının verileri temelde, seçilen mahallelerde yapılan derinlemesine görüşmeler, odak grup görüşmeleri ve katılımcı gözlemler aracılığ Türkiye kökenli nüfusun yoğun olarak yaşadığı mahalleler araştırmaya dahil edilmiştir. Bkz. Ece Öztan, Göç Bağlamında Yurttaşlık ve Toplumsal Cinsiyet: Türkiye Kökenli Amsterdamlı Kadınların Yurttaşlık Deneyimleri, Doktora Tezi, (İstanbul: Marmara Üniversitesi, 2009).

${ }^{9}$ Godula Kosack, “Migrant Women: the Move to Western Europe - a step towards Emancipation?", Race and Class, 17, no.4 (1976): 369-380.

${ }^{10}$ Nermin Abadan-Unat'ın Almanya iş piyasasında Türk kadınlarının konumuna yer verdiği çalışmalardan bazıları şunlardır: Batı Almanya'daki Türk İşçileri ve Sorunları, (Ankara: Başbakanlık Devlet Planlama Teşkilatı, 1964); “Federal Almanya'nın 1966-67'de Geçirdiği Ekonomik Buhran Açısından Yabancı İşgücü ve Türk İşçilerinin Durumu”, A.Ü. S.B.F. Dergisi, 26, no.4 (1971):159-180; Turkish Workers in Europe, 1960-1975: A Socio-Economic Reappraisal. (Leiden: E. J Brill, 1975); "Implications of Migration on Emancipation and Pseudo-Emancipation of Turkish Women”, International Migration Review, 11, no.1 (1977): 31-57 ve Bitmeyen Göç: Konuk İşçilikten Ulus-ötesi Yurttaşlığa (İstanbul : İstanbul Bilgi Üniversitesi Yayınları, 2002).

${ }^{11}$ 1966-67 Batı Almanya'daki iktisadi durgunluk dönemidir ve hemen ertesinde Alman endüstrilerinin ucuz emek ihtiyacını karşılamak üzere göçmen kadın işgücünden sıklıkla yararlanmaya başlamıştır. Abadan-Unat, 1966 öncesindeki dönemde istihdam edilen göçmen kadın işçileri 1. Dalga, 1966 sonrasındakileri ise 2. Dalga olarak ayırmaktadır. Özellikle ilk dalga ile gelen Türk kadınlarının, hem aynı dönemde gelen erkek işçiler hem de 2. dalga ile gelen diğer kadın işçilerden eğitim, kır-kent kökeni vb. nitelikler açısından farklılaştığının altını çizmektedir. Bkz. Abadan-Unat, Batı Almanya 'daki, 61; "Implications of", 35.

${ }^{12}$ Çağlar Keyder ve Ayhan Aksu-Koç, External Labour Migration from Turkey and Its Impact, (Ottawa: International Development Research Centre, 1988): 22.

${ }^{13}$ Abadan-Unat, Implications of, 33 ve Bitmeyen Göç, 149.

${ }^{14}$ Lenie Brouwer ve Marijke Priester, "Living in between: Turkish women in their homeland and in the Netherlands", der. Annie Phizacklea, One-Way Ticket: Migration and Female Labour, (London: Routledge \& Kegan Paul, 1983): 113-129.

${ }^{15}$ Çalışma Bakanlığı Yurtdışı İşçi Sorunları Genel Müdürlüğü, Yurtdışı İşçi Sorunları '81, (Ankara: Başbakanlık Basımevi, 1981), Keyder ve Aksu-Koç, External Labour, s. 22 içinde.

${ }^{16}$ Kosack, "Migrant Women", 372-3.

${ }^{17}$ Kofman, "Female' birds,", 274.

${ }^{18}$ Özellikle Kuzey Amerika bağlamındaki çalışmalardan hareketle Hondagneu-Sotelo bu dönemde önce, bir önceki dönemin "göç ve kadın" yaklaşımının yerini "göç ve toplumsal cinsiyet" yaklaşımına bıraktı̆̆ını belirtmektedir. Göç ve toplumsal cinsiyet yaklaşımında toplumsal cinsiyet göç tarafindan biçimlendirilen ve göçü biçimlendiren bir dizi sosyal pratik olarak kavranmakta ve araştırmalar yine genellikle yalnızca kadınlarla yapılmaktadır. Hondagneu-Sotelo, "Gender and,", 7.

${ }^{19}$ Annie Phizacklea (der.), One-Way Ticket: Migration and Female Labour, (London: Routledge \& Kegan Paul, 1983)

${ }^{20}$ Örneğin Avrupa'da 1970'lerden sonra aile birleşimi yoluyla göçmen kadınların sayısında öngörülmedik artış, kadınların bir sorun olarak gündeme gelmesinde belirleyicidir. Bu dönemden itibaren göçmen kadınlar, özellikle "farklı" ve "egzotik" yönleri, "geleneksellik ve eşitsiz cinsiyet ilişkilerinin baskısı altında" kadınlar olarak Avrupalı feminist yazarların da ilgi odağı olmuştur. Erder, "Uluslararası Göç,”, 302;305.

${ }^{21}$ Hondagneu-Sotelo, "Gender and Immigration", 6.

${ }^{22}$ Patricia P. Pessar, "Engendering Migration Studies: The Case of New Immigrants in the United States", der. P. Hondagneu-Sotelo, Gender and U.S. Immigration: Contemporary Trends, (California: University of California Pres, 2003).

${ }^{23}$ Abadan-Unat, "Implications of".Jennifer A. Miller, 
${ }^{24}$ Jennifer A. Miller, Postwar Negotıatıons: The First Generatıon Of Turkısh —Guest Workersil In West Germany, 1961-1973, Doktora Tezi, (Rutgers-The State University of New Jersey: 2008).

${ }^{25} 1960$ sonrasında Hollanda vasıfsız işler ve eski emek yoğun endüstriler için Türkiye ve Fas'tan gelen "misafir işçileri” istihdam etmeye başlamıştı. "Misafir işçilik" tanımlamasının gerisinde, gelenlerin Hollanda'daki varlıklarının geçici olduğu düşüncesi yatmaktaydı. İşçi alımı anlaşmaları Türkiye ile 1963, Fas ile 1969 yıllarında yapılmıştı. Fakat ilk dönemlerde gelenler sayısal olarak sonraki dönemlerle karşılaştırıldığında daha düşüktü. 1973 petrol krizi beraberinde Hollanda'nın işçi alımlarını durdurması sonrasında da Türkiye ve Fas'tan aile birleşimi göçü artarak devam etmişti ve 1979 ve 1980 yılları gelenlerin sayısının zirveye ulaştığı yıllar olmuştu. 1980'li yılların ortalarından itibaren, Türkiye ve Fas'tan aile birleşimi yoluyla gelenlerin sayısında tekrar nemli artışlar yaşanmıştır. Bu dönem aile birleşimi sürecinde gelenler daha çok evlilik sonucunda Hollanda'ya gelen genç kadın ve erkeklerdi. Bu göçü ilk dönem aile birleşimi göçünden ayırmak için "evlilik göçü” deyimi kullanılmaktadır. Bkz. Hans Vermeulen ve Rinus Penninx, Immigrant Integration The Dutch Case, (Amsterdam: Het Spinhuis, 2000), 7-8.

${ }^{26}$ Kofman, "Female' birds,".

${ }^{27}$ Örneğin 2002 verilerine göre Hollanda 15 milyonluk nüfusu ile dünyadaki toplam yabancı doğrudan yatırımlar içerisinde \% 5'lik bir paya sahiptir (Jones, 2005: 233). Ayrıca bugün Shell, Unilever, Phillips gibi Avrupa'nın en büyük çokuluslu şirketlerin sermayesinde ağırlıklı bir paya sahiptir. Buna paralel gelişmiş ve bir bankacılık ve finans sektörü ile Hollanda, küresel kapitalizme tam eklemlenmiş bir iktisadi alt yapıya sahiptir.

${ }^{28}$ Marlou Schrover, "Family in Dutch migration policy 1945-2005". The History of the Family 14 no.2, (2009), 196; Froukje Santing, O Kadın Benim İşte. (Rotterdam: Samen Wonen Samen Leven Derneği, 1987), 75.

${ }^{29}$ Mirjana Morokvasic, "Women in migration: beyond the reductionist Outlook" One way ticket: Migration and female labour, der. A. Phizacklea (London: Routledge and Kegan Paul. 1983): 13-31; Morokvasic, "The overview: Birds,".

${ }^{30}$ Ahmet Akgündüz, Labor migration from Turkey to Western Europe, 1960-1974. A Multidisciplinary Analysis. Doktora Tezi, (Amsterdam: Universiteit van Amsterdam, 2006), 183; 196.

31 Literatürde de genellikle okul yaşından sonra (6-18) göç ülkesine gelen gruplar 1,5. nesil ya da "ara nesil" olarak adlandırılmaktadır. Burada 1,5. ve 2. kuşak arasında ayrım yapmamızın en temel nedeni, eğitim yaşamı ve sosyalleşme bakımından iki grup arasında kimi farklılıkların oluşmasıdır. Başta dil olmak üzere, eğitim hayatının göç nedeni ile kesintiye uğraması nedeniyle yaşanılan sorunlar ara kuşak kadınların deneyimlerini 1. kuşak kadınlarla yakınlaştırmaktadır.

${ }_{32}$ Evlilik göçü de hukuki bakımdan bir "aile birleşimi” göçüdür. Literatürde, ilk dönemin eş ve babayı takiben gerçekleşen aile birleşiminden farkını ortaya koymak için, "evlilik göçü” tanımlaması kullanılmaktadır. Sıklıkla kullanılan "ithal gelin" veya "ithal damat" lar da bu grupta yer almaktadır.

33 Örneğin 1970'lerde Hollandalı kadınların iş piyasasına katılım oranı \% 30 düzeyindeydi. Bkz. Ans Merens, ve Brigette Emancipatiemonitor 2008 (Den Haag: Sociaal en Cultureel Planbureau / Centraal Bureau voor de Statistiek, 2009).

${ }^{34} \mathrm{Bu}$ makalede kullanılan bütün isimler takma isimlerdir.

${ }^{35}$ Hollanda örneğinde yarı-zamanlı çalışma ve "ev hanımı sözleşmesi” modelinin yerli ve göçmen kadınların istihdam, aile ve özgürleşme örüntülerine etkisi konusundaki değerlendirmeler için bkz. Ece Öztan, "Göçmen Kadınlar ve Anneliğin Düzenlenmesi: Amsterdamlı Türkiye Kökenli Kadınların Annelik Deneyimleri, Toplum ve Bilim, 119 (2010): 111-140.

${ }^{36}$ Fordist çalışma ilişkilerinin ürünü patriarkal ailenin geçirdiği dönüşüm ile ortaya çıkan "bakım krizi” ile küresel bakım zincirlerinin, cinsellik, evlilik ve eğlence alanında "beden pazarlarının" oluşumu, ulusaşırı temizlikçiler, bakıcılar, hemşireler ordusu veya bilişim teknolojilerindeki gelişmeler ile ulusaşırı tele-hizmetlerin gelişimi veyahut küresel meta zincirleri yoluyla üretimin ucuz, enformel emeğe dayanan çevre ülkelerine kayması gibi gelişmeler cinsiyetlenmiş yeni iş piyasalarında her türlü güvenceden yoksun, ucuz, tehlikeli, riskli veyahut tüketici esnek istihdam biçimlerinin örneklerindendir.

${ }^{37}$ Çalışma izni olmaksızın ve/veya sigortasız kayıt dışı çalışma için kullanılmaktadır.

${ }^{38} 2,5-3,5$ Euro.

${ }^{39}$ Erder, "Uluslararası Göç,", 303.

${ }^{40}$ Fortuijn'in belirttiği gibi "toplumsal cinsiyet sözleşmesi” bakımından Hollanda toplumu bir "ev hanımı sözleşmesi” modelini sürdürmektedir. Bu model, kadınlar için yarı-zamanlı bir iş piyasası ile desteklenmektedir. Joos D. Fortuijn, "City and Suburb: Contexts for Dutch Women's Work and Daily Lives", Women of the European Union: The Politics of Work and Daily Life der. J. M. J. Momsen (London \& NY: Routledge, 1996), 217-228. İş piyasası sorunlarına "Hollanda mucizesi" olarak adlandırılan çözüm, yarı zamanlı ve esnek çalışmayı kolaylaştıran ve teşvik eden bir dizi yasa ile sağlanmıştır. Kadınların ücretli işgücüne daha yoğun olarak katılmaya başlaması sonrasında dahi, toplumsal cinsiyet rejimi erkeğin ekmek kazanan kadınınsa temelde bakım işini yarı zamanlı ücretli bir işle kombine ettiği "bir buçuk modeli” olarak adlandırılan bir aile formunda devam etmiştir. Son verilere göre Hollanda'da çalışan kadınların hemen hemen \% 70’i yarı zamanlı olarak çalışmaktadır. Bkz. Merens ve Hermans, Emancipatiemonitor, 26. Çalışan kadınlar arasındaki ortalama çalışma saatleri 1995'ten bu yana düşme göstermektedir. Bu nedenle ortalama çalışma saatlerinin düşmesi, işgücüne katılan kadın sayısındaki artışı nötrleştirmektedir. Küçük çocukları olan kadınların hemen hemen hepsi yarı-zamanlı işlerde çalışmaktadır.

${ }^{41}$ Saskia Keuzenkamp ve Ans Merens, Sociale atlas van vrouwen uit etnische minderheden. (Den Haag: Sociaal en Cultureel Planbureau, 2006), 21-25.

42 Türkiye kökenli kadınların, iş piyasasına katılım oranları son verilere göre \% 38 seviyesindedir. Bu oran Hollandalı kadınlarda \% 59, Türkiye kökenli erkeklerde \%63, Hollandalı erkeklerde ise \% 77 düzeyindedir. Ancak sonraki kuşaklar açısından tablo farklılaşmaktadır. (Keuzenkamp ve Merens, Sociale atlas, 84). Çalı̧̧an göçmen kadınlar, Hollandalı kadınlara oranla daha çok tam zamanlı işlerde çalışmaktadır (Keuzenkamp ve Merens, Sociale atlas, 91). Düşük eğitimli bir kadının ödenek aldığı durumdaki refah seviyesini geçebilmesi için haftada minimum 32 saat çalışması gerektiği hesaplanmıştır (Knijn, Trudie ve Frits van Wel, Alleenstaande ouders over Zorgen en Werken, ('s Gravenhage: Ministerie van Sociale Zaken en Werkgelegenheid/Elseviers Bedrijfsinformatie, 2000).

${ }^{43}$ Floya Anthias, Nira Yuval-Davis, Racialized boundaries: race, nation, gender, colour, and class and the anti-racist struggle (London; New York: Routledge, 1992). 
${ }^{44}$ Philomena Essed, Diversity: gender, color, and culture (University of Massachusetts Pres, 1996)

45 Dirk Jacobs, "Discourse, politics and Policy. The debate over voting rights for foreign residents in The Netherlands (1970-1996)" International Migration Review, 32, no. 2 (1998): 350-73.

${ }^{46} \mathrm{Bu}$ bağlamda göçmen topluluğa yönelik hizmetlerin örgütlenmesi ve Türk toplumuna yönelik örgütlenme faaliyetlerinin hız kazanmasında 1980'li yıllardan Türkiye'den gelen siyasi sığınmacıların da önemli bir etkisi olmuştu. Sığınmacılar Hollanda’ya yalnız Türkiye'deki ideolojik çatışma ve farklı grupların siyasi örgütlenme çizgilerini taşımakla kalmadılar, Hollanda'daki göçmen topluluğuna yönelik örgütlenme faaliyetlerinde yetişmiş işgücü ihtiyacını da karşıladılar. Ayrıca Hollanda'da giderek marjinalleşen pek çok sol grubun da faalleşmesinde rol oynadılar.

${ }^{47}$ Hollanda'da göçmen örgütleri için yerleşik bir terim bulunmaktadır: "Zelf-organisatie”, yani “öz-örgütler”. Öz-örgüt terimi, etnik azınlık ve göçmenler tarafından oluşturulan örgütlenmeleri ifade etmektedir. Öz-örgüt terimi, basit bir adlandırma olmasının ötesinde, farklılıkların yönetimi ve Hollanda çokkültürcü siyasetinin izlerini taşır. Hollanda'daki Türkiye kökenli topluluğun diğer göçmen topluluklarına oranla daha yoğun bir örgütlenme içinde olduğu kabul edilmektedir (Bkz. Jean Tillie, "Social capital of organisations and their members: explaining the political integration of immigrants in Amsterdam", Journal of Ethnic and Migration Studies, 30, no. 3, (2004): 529-541. Özellikle 1980'lerden itibaren uygulanan çokkültürcü politikaların etkisiyle göçmen örgütlenmelerinin kamusal fonlarla desteklenmesi bu tür yoğun ve iç içe geçmiş bir örgütlenme yapısının gelişmesinde etkili olmuştur. Ayrıca Hollanda'nın siyasal müzakere geleneği ve sütunlaşmanın mirası göçmen grupların örgütlenme deneyimlerine de zemin olmuştur.

${ }^{48}$ Frank Olaf Radtke, "The formation of ethnic minorities and the transformation of social into ethnic conflicts in a socalled multicultural society: the case of Germany". Ethnic Mobilisation in a Multi-cultural Europe der. J. Rex \& B. Drury (Aldershot: Avebury, 1994): 30-37.

${ }^{49} 1990$ 'lı yılların ortalarında yapılan bir araştırmaya göre Hollanda'daki Türk derneklerinin dörte üçünden fazlasının yönetim kurullarında tek bir kadın bile bulunmadığı, diğerlerinde ise ise sadece bir kadının -ve muhtemelen sadece kadınlarla ilgili konularla uğraşmak üzere orada bulunan- yönetim kurulunda yer aldığı belirlenmiştir (Hatice Can-Engin ve Murat Can, Siyah Lale. Göçün 40. Yllında Hollanda'da Türkler, (Rijen: Dizayn, 2003), 112.

${ }^{50}$ Essed, "Diversity: gender,", 142.

${ }^{51}$ HTIB, 12 Mart 1971 muhtırası sonrasındaki dönemde Türkiye'den ayrılan Türkiye Komünist Partisi (TKP) üyelerinin girişimiyle Utrecht'te kurulmuştu. Daha sonra derneğin merkezi Amsterdam'a taşınmıştır. HTỉB halen Hollanda'nın beş şehrinde (Amsterdam, Leiden, Den Haag, Rotterdam ve Eindhoven) önceki dönemle kıyaslanabilir olmasa da faaliyetlerine devam etmektedir. O dönem, Türkiye'de de, TKP'nin BM Dünya Kadın On yılı öncesindeki çağrısıyla paralel bir şekilde, İlerici Kadınlar Derneği(IKD) kurulmuştu. HTKB'nin Türkiye'deki İKD ile de yakın bağlantıları ve ortak çalışmaları olmuştur.

${ }^{52}$ HTKB kökenli görüşmeciler, örgütlenme deneyimlerinin “TKP'lilerin eşleri”" etiketi ile anılmasına karşı da önemli bir mücadele vermeleri gerektiğini vurgulamışlardı.

${ }^{53}$ HTKB'nin 20 yılı aşkın bir süreyi kapsayan örgütlü faaliyetlerine ilişkin belgeler Amsterdam'da bulunan Uluslararası Sosyal Tarih Enstitüsü'nde (IISG) bulunmaktadır. 10 metreyi aşkın raf uzunluğu bulunan arşiv, o dönemde yürütülen çalışmaları ve emeği gözler önüne sermektedir. HTKB arşivine ilişkin döküme Uluslararası Tarih Enstitüsü'nün web sayfasından ulaşılabilir: http://www.iisg.nl/archives/en/files/h/10815458.php . Bu arşivin büyük bir bölümü IISG'de yer almakla birlikte, Kadın Hareketi Uluslararası Arşiv ve Bilgi Merkezi (IIAV- Internationaal Informatiecentrum en Archief voor de Vrouwenbeweging, Amsterdam) arşivlerinde de örgüt ile ilgili bazı belge ve görsel malzemeler bulunmaktadır.

${ }^{54}$ Zülfikar Özdoğan, “Bir Zamanlar HTKB Vardı!”, HTIB, 8 Mart 2008, http://www.htib.nl/htkb8mart.html , (erişim: 05.06.2010).

${ }_{55}$ 1990’lı yıllarda bir ayrışma yaşayan HTKB, 1995 yılında yapılan kongrede feshedilerek bugün Hollanda Türkiyeli Kadınlar Federasyonu ve Amsterdam Türkiyeli Kadınlar Birliği olarak iki yeni örgüt oluşturulmuş, eski dönemde HTKB içerisinde yer alan pek çok kadın da örgütten ayrılmıştır.

${ }_{56}$ Volkhuizen (halk evleri), clubhuizen (klüpler) gibi çeşitli adlar alan semt evleri (buurthuizen) Hollanda'da 19. yy'ın sonlarından itibaren gündeme gelmeye başlayan bir sosyal hijyen doktrinin etkisiyle, kentsel yoksullar, asosyal aileler ya da işçi sınıfının çeşitli segmentlerine yönelik bir düzenleme ve denetleme aracı olarak hayata geçirilmiş, sosyal hizmet alanındaki dönüşümler paralelinde kurumsallık kazanmıştır. Bu merkezler, 1960 ve 70’li yıllarda dönemin yeni toplumsal hareketlerinin de etkisiyle siyasallaşmaya başlamış ve sosyal uyumdansa sosyal değişim yönünde bir çabanın konusu olmuştur.

${ }^{57} \mathrm{O}$ dönemin HTKB'li kadınları ile yaptı̆ğım görüşmelerde, geliştirdikleri bu projenin Vrouw Werkwinkel yani Kadın Çalışma Büroları ile ortak olarak yürütülmekte olan bir projelerden biri olduğunu öğrendim. Ancak, bu kadın çalışma büroları sonradan genel iş bulma kurumlarına (arbeidsbureau) devredilmesinin kadınların iş pazarına katılımına odaklanan önemli bir birimin ortadan kaldırılması bakımından çok olumsuz bir etkisi olduğu dile getirilmiştir.

${ }^{58}$ Sosyal akademiler, yüksekokul düzeyinde genel olarak sosyal hizmet eğitimi veren okullardır.

${ }^{59}$ Mesleki eğitimi de içeren entegrasyon programları başlangıçta yetişkinlere yönelik eğitim veren Bölgesel Mesleki Eğitim Kurumları (ROC) aracılığıyla yürütülmüştür.

${ }^{60}$ Essed, "Diversity: gender,",117.

${ }^{61}$ IISH, HTKB Arşivi No: 209, Texel Eğitim Toplantısı Raporu (1-2 Ekim 1983).

62 Avrupa Türkiyeli Kadınlar Kongresi'nde bu toplantının "Türkiyeli kadınların tartışma konusu bir nesne olarak değil, bizzat kendilerinin düzenlediği ve söz sahibi olduğu ilk uluslararası toplantı” olduğu vurgulanıyordu. HTKB, 'Sesini Yükselt!' Türkiyeli Göçmen Kadınlar Avrupa Konferansı Raporları ve Önerleri, (Amsterdam, Ekim 1986),10. Kongrede, Yasal Haklar ve Hükümet Politikaları, Irkçılık Ayrımcılık ve Yabancı Düşmanlığı, Eğitim, İstihdam, Sağlık, Kültür, Örgütlenme ve Genç Kızlar başlıklı 8 ayrı çalışma grubu oluşturulmuş, bu grupların oluş̧urduğu raporlar özet halinde bir kitapçıkta toplanmıştır. Konferansa ilişkin tüm belgeler Uluslararası Sosyal Tarih Enstitüsü’ndeki HTKB Arşivinde yer almaktadır. IISG, HTKB Arşivi, No: 243-254 (1985). Ayrıca derlenmiş kongre raporları için bkz. HTKB, "'Sesini Yükselt!',".

${ }^{63}$ Mandana Hendessi, "Fourteen Thousand Women Meet: Report from Nairobi, July 1985. Feminist Review, 23 (1986), 154. 147-156

${ }^{64}$ Özden Yalım, "Passing on 'Invisible' Histories- New Media and the Cultutal Heritage of Immigrant Women in the Netherlands", Traveling Heritages der. S. E. Wieringa (Amsterdam: Aksant, 2008), 187. 


\section{Kaynakça}

Abadan-Unat, Nermin, Batı Almanya’daki Türk İşçileri ve Sorunları, (Ankara: Başbakanlık Devlet Planlama Teşkilatı, 1964).

Abadan-Unat, Nermin, “Federal Almanya'nın 1966-67’de Geçirdiği Ekonomik Buhran Açısından Yabancı İşgücü ve Türk İşçilerinin Durumu”, A.Ü. S.B.F. Dergisi, 26, no.4 (1971):159-180.

Abadan-Unat, Nermin, Turkish Workers in Europe, 1960-1975: A Socio-Economic Reappraisal, (Leiden: E. J Brill, 1975).

Abadan-Unat, Nermin, "Implications of Migration on Emancipation and Pseudo-Emancipation of Turkish Women”, International Migration Review, 11, no.1 (1977): 31-57.

Abadan-Unat, Nermin, Bitmeyen Göç: Konuk Iş̧̧ilikten Ulus-ötesi Yurttaşlı̆̆a (İstanbul: İstanbul Bilgi Üniversitesi Yayınları, 2002).

Akgündüz, Ahmet, Labor migration from Turkey to Western Europe, 1960-1974. A Multidisciplinary Analysis. Doktora Tezi, (Amsterdam: Universiteit van Amsterdam, 2006).

Anthias, Floya ve Yuval-Davis, Nira, Racialized boundaries : race, nation, gender, colour, and class and the antiracist struggle (London; New York: Routledge, 1992).

Brouwer, Lenie ve Marijke Priester, "Living in between: Turkish women in their homeland and in the Netherlands", der. Annie Phizacklea, One-Way Ticket: Migration and Female Labour, (London: Routledge \& Kegan Paul, 1983): 113-129.

Castles, Stephen ve Miller, Mark J., The Age of Migration, International Population Movements in the Modern World (London: Palgrave Macmillan, 1993).

Engin, Hatice Can ve Can, Murat, Siyah Lale. Göçün 40. Yılında Hollanda'da Türkler, (Rijen: Dizayn, 2003)

Erder, Sema, “Uluslararası Göç Sürecinde Kadının Gündeme Gelişi ve 'Getto'daki Kadın”, Refah Toplumunda Getto (İstanbul: İstanbul Bilgi Üniversitesi Yayınları, 2006): 299-320.

Essed, Philomena, Diversity: gender, color, and culture (University of Massachusetts Pres, 1996)

Fortuijn, Joos D. “City and Suburb: Contexts for Dutch Women's Work and Daily Lives", Women of the European Union: The Politics of Work and Daily Life der. J. M. J. Momsen (London \& NY: Routledge, 1996), 217228.

Hendessi, Mandana, "Fourteen Thousand Women Meet: Report from Nairobi, July 1985. Feminist Review, 23 (1986), 147-156.

Hondagneu-Sotelo, Pierrette ve Cranford, Cynthia, Gender and migration (California: Springer, 1999).

Hondagneu-Sotelo, Pierrette, "Gender and Immigration. A Retrospective and Introduction” Gender and U.S. Immigration: Contemporary Trends der. P. Hondagneu-Sotelo (California: University of California Pres, 2003), 3-19.

HTKB, 'Sesini Yükselt!' Türkiyeli Göçmen Kadınlar Avrupa Konferansı Raporları ve Önerleri, (Amsterdam, Ekim 1986).

Jacobs, Dirk , "Discourse, politics and Policy. The debate over voting rights for foreign residents in The Netherlands (1970-1996)" International Migration Review, 32, no. 2 (1998): 350-73.

Keyder, Çağlar ve Ayhan Aksu-Koç, External Labour Migration from Turkey and Its Impact, (Ottawa: International Development Research Centre, 1988).

Knijn, Trudie ve Frits van Wel, Alleenstaande ouders over Zorgen en Werken, ('s Gravenhage: Ministerie van Sociale Zaken en Werkgelegenheid/Elseviers Bedrijfsinformatie, 2000).

Kofman, Eleonore, "Female' birds of passage'a decade later: Gender and immigration in the European Union" International Migration Review 33, no. 2 (1999): 269-299.

Kosack, Godula, “Migrant Women: the Move to Western Europe - a step towards Emancipation?”, Race and Class, 17, no.4 (1976): 369-380.

Mahler, Sarah ve Pessar, Patricia, "Gender matters: ethnographers bring gender from the periphery toward the core of migration studies", International Migration Review 40, no. 1 (2006): 27-63.

Merens, Ans ve Hermans, Birigette, Emancipatiemonitor 2008 (Den Haag: Sociaal en Cultureel Planbureau / Centraal Bureau voor de Statistiek, 2009). 
Miller, Jennifer A. Postwar Negotıatıons: The Fırst Generatıon Of Turkısh - Guest Workers in West Germany, 19611973, Doktora Tezi, (Rutgers-The State University of New Jersey: 2008).

Morokvasic, Mirjana. "Women in migration: beyond the reductionist Outlook" One way ticket: Migration and female labour, der. A. Phizacklea (London: Routledge and Kegan Paul. 1983): 13-31.

Morokvasic, Mirjana, “The overview: Birds of Passages are also Women”, International Migration Review. Women in Migration. Special Issue 18, no. 4 (1984): 886-907.

Özdoğan, Zülfikar, “Bir Zamanlar HTKB Vardı!”, HTIB, 8 Mart 2008, http://www.htib.nl/htkb8mart.html , (erişim: 05.06.2010).

Öztan, Ece, Göç Bağlamında Yurttaşlık ve Toplumsal Cinsiyet: Türkiye Kökenli Amsterdamlı Kadınların Yurttaşlık Deneyimleri, Doktora Tezi, (İstanbul: Marmara Üniversitesi, 2009).

Öztan, Ece, “Göçmen Kadınlar ve Anneliğin Düzenlenmesi: Amsterdamlı Türkiye Kökenli Kadınların Annelik Deneyimleri, Toplum ve Bilim, 119 (2010): 111-140.

Pessar, Patricia P., "Engendering Migration Studies: The Case of New Immigrants in the United States", Gender and U.S. Immigration: Contemporary Trends der. P. Hondagneu-Sotelo (California: University of California Pres, 2003), 20-42.

Phizacklea, Annie (der.), One-Way Ticket: Migration and Female Labour, (London: Routledge \& Kegan Paul, 1983)

Radtke, Frank-Olaf, "The formation of ethnic minorities and the transformation of social into ethnic conflicts in a socalled multi-cultural society: the case of Germany". Ethnic Mobilisation in a Multi-cultural Europe der. J. Rex \& B. Drury (Aldershot: Avebury, 1994): 30-37.

Schrover, Marlou, "Family in Dutch migration policy 1945-2005”. The History of the Family 14, no.2 (2009): 191-202

Vermeulen, Hans ve Penninx, Rinus, Immigrant Integration The Dutch Case, (Amsterdam: Het Spinhuis, 2000).

Yalım, Özden, "Passing on 'Invisible' Histories- New Media and the Cultutal Heritage of Immigrant Women in the Netherlands", Traveling Heritages der. S. E. Wieringa (Amsterdam: Aksant, 2008), 185-198. 